
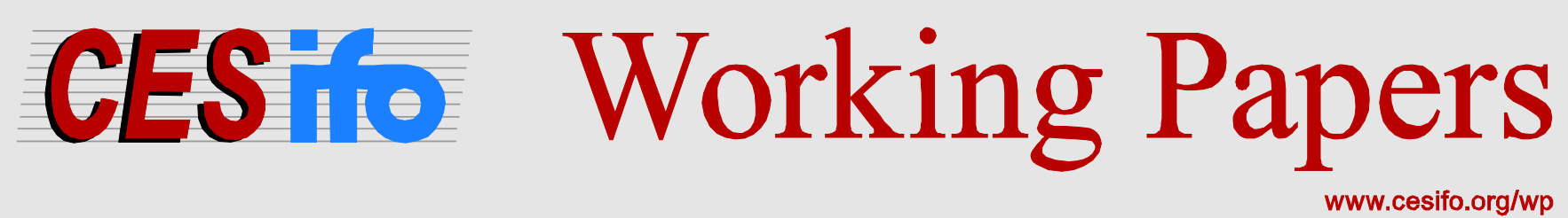

\title{
Measurement and Determinants of Access to Loans
}

\author{
Christa Hainz \\ Tatjana Nabokin
}

\author{
CESIFO WORKING PAPER NO. 4190 \\ CATEGORY 12: EMPIRICAL AND THEORETICAL METHODS \\ APRIL 2013
}

An electronic version of the paper may be downloaded

- from the SSRN website:

- from the RePEc website:

- from the CESifo website:

wWw.SSRN.com

Www.RePEc.org

www.CESifo-group.org/wp

\section{CESifo}




\title{
Measurement and Determinants of Access to Loans
}

\begin{abstract}
Measuring and identifying financial constraints represents an important challenge in empirical studies. Due to data limitations perception-based indicators or approximations of access to finance by the usage of finance are often used, disregarding firm-specific differences in the demand for external finance. Using unique firm-level survey data, which provide information on a firm's credit demand, we develop a direct measurement for access to credit and provide for the first time an empirical evaluation of these methods. We find that information on the usage of credit is not sufficient to identify financially constrained firms, while perception based indicators are surprisingly precise. The paper concludes by presenting recommendations for future survey design.

JEL-Code: G210, O160.

Keywords: access to finance, usage of finance, credit demand, perceived access to finance.

Christa Hainz
Ifo Institute - Leibniz-Institute
for Economic Research
at the University of Munich
Poschingerstraße 5
Germany-81679 Munich
hainz@ifo.de
\end{abstract}

March 2013

We gratefully acknowledge financial support from the German Science Foundation (DFG) through GRK 801 and project HA3039/3-1 and from the Max Planck Society through IMPRS-CI. We received helpful comments from Martin Brown, Colin Cameron, Alexander Danzer,Maria Lehner, Jörg Rocholl, Monika Schnitzer, Christiane Ströh, Linda Rousova, Eva Terberger, Joachim Winter and from participants at the Annual Congress of the European Economic Association in Malaga, the Annual Conference of the International Society for New Institutional Economics in Stirling, the Ifo/CESifo \& ACES Conference on Banking and Institutions in Munich, the Spring Meeting of Young Economists in Luxembourg, the Annual Congress of the German Economic Association in Magdeburg, the Annual International Conference of the German Economic Association Research Committee on Development Economics in Bonn and the IO and Trade Seminar at the University of Munich. All remaining errors are our own. 


\section{Introduction}

Access to finance is regarded as a major determinant of economic growth and development and has been an important policy goal for developing countries. ${ }^{1}$ During the recent financial crisis bank lending has decreased often dramatically. The resulting credit crunches forced firms to cut their investments (e.g. Campello et al., 2010) and had negative impacts on economic growth. To contain these adverse effects governments took a variety of measures to improve the access to credit for firms, including the provision of public guarantees for loans to particular industries (OECD, 2011). In order to answer the question of how policy measures should be best designed to foster access to finance, a precise measurement of financial constraints is necessary. Direct measurements of access to finance are, in many cases, not available due to data limitations and indirect proxies have to be used. Access to finance is often approximated by the usage of finance. However, this approach neglects the fact that firms that do not use external finance can either be financially constrained or might have no demand for external finance. The same is true for perception-based indicators: firms reporting that they do not suffer from financial constraints may either have sufficient access to finance or may have no demand for it. For the first time to our knowledge, this paper provides an empirical evaluation of these approximative measurements of access to credit. To this end it addresses the following questions: what are the determinants of access to credit? Are measurements based on the usage of credit valid approximations for access to credit? Do perception-based indicators allow to precisely identify and predict credit constraints?

To answer these questions we use the Business Environment and Enterprise Performance Survey (BEEPS), which contains detailed firm-level survey data for 9,655 firms in 27 countries in Europe and Central Asia. This data set provides a unique source of financial information on credit financing, which is a prior source of external finance for small- and medium enterprises (SME) in general, and for firms in developing countries in particular, and allows us to circumvent using indirect measurements of access to loans. In the survey firms were asked not only whether they have a bank loan, but also to state the reasons why they do not use loans. The answers can be broadly divided into two categories - either a firm was restricted from

\footnotetext{
${ }^{1}$ E.g. Rajan and Zingales (1998); Beck et al. (2000). For developing countries, there are several studies that use either policy changes or controlled experiments to estimate the effect of credit constraints on firm performance (for a survey, see Beck and Demirgüç-Kunt, 2008). Karlan and Murduch (2009) provide a comprehensive overview on the topic in the context of development economics.
} 
access to credit or it did not have any demand for it. In a first step, we develop a direct measure of access to credit, which takes into account whether a firm that needs credit is successful in obtaining a loan. By controlling for demand we can differentiate between firms that are denied access and firms that do not need credit, whereby - for the purpose of analyzing access to credit - only the first group is relevant. We additionally control for a possible selection bias, as the selection into the demand group might not be random. This allows us to consistently estimate the determinants of access to credit. In a second step, we compare the access and the usage approach regarding the identified determinants of credit constraints in order to highlight the differences between both methods and to evaluate whether information on the usage of loans is sufficient to identify credit constraints. ${ }^{2}$ Finally, we investigate whether a perception-based indicator is precise enough to identify the same determinants as a direct measurement of access to credit.

Our analysis yields three important results. First, we can separate the determinants influencing demand from those affecting access. On the firm level, our results show that domestic firms, investing firms and firms perceiving competition as more intense have a higher probability of demanding a loan. Small firms, as well as foreign and state-owned firms, demand loans less frequently. Given that a firm experience demand, profitable, transparent and foreign-owned firms have better access to credit, while young and small firms face a higher risk of being credit constrained. On the country level, in particular better creditor rights are associated with better access to credit. Second, a comparison of these estimates with those of the usage estimations, reveals considerable differences. Our findings suggest that the demandand the access-effect are not disentangled and interfere in the usage-approach. We conclude that approximating access to credit by usage does not make it possible to identify credit constraints. Finally, evaluating the perception-based indicators, we find that these measures can predict credit constraints very precisely, even when information on credit demand is not available.

This paper is related to the literature on access to finance and how it is determined by firmand country-specific characteristics. In this literature a variety of measurements for access to

\footnotetext{
${ }^{2}$ Unfortunately the World Bank Environment Survey (WBES), which covers more developing countries and is the equivalent survey to BEEPS, does not make it possible to study this question as information on credit need necessary to construct a direct measure of access to credit - and information on the usage of credit do not refer to the same period of time and therefore cannot be matched precisely.
} 
finance have been used. ${ }^{3}$ Basically, the financial situation of firms has been evaluated by using balance-sheet or survey data. Balance-sheet data provide information about which sources of finance are actually used and to what extent. Information from the annual report can indicate that financial constraints exist when firms cannot fulfill covenants. Furthermore balance-sheet data have been used to analyze the sensitivity of investment to cash flows as an indicator of financial constraints (Fazzari et al., 1988). However, there is a considerable debate about this approach (Kaplan and Zingales, 1997, 2000). Since reliable balance-sheet data are needed, this approach is most appropriate for studying large corporations. If the research interest concerns SME or firms from developing countries or emerging markets, comprehensive data on balance-sheet information is often an issue.

A large strand of the literature on the determinants of access to finance is based on survey data, and often uses perception based indicators for access to finance and cost of finance or approximations based on the usage of finance. Beck et al. (2006) show that perceived access is influenced by size, age and ownership. Brown et al. (2009) provide evidence that information sharing among banks improves the perceived availability and cost of credit and increases the usage of external finance (in terms of firm debt relative to total assets), particularly for opaque firms and in countries with a weak institutional environment. With respect to institutions, Safavian and Sharma (2007) find that the quality of the legal system and its enforcement are complements, whereby the usage of loans (as a dummy variable or as the share of new investments financed through loans) is the dependent variable. Giannetti and Ongena (2009) show that better financial integration in terms of foreign bank lending increases the usage of debt. At the same time, an increased foreign bank presence leads to a higher growth rate among firms, which indirectly indicates that the demand for external finance has also been raised. To summarize, it is not always clear whether an overall increase in the usage of external finance or better perceived access goes along with actually improved access to finance, when the demand for external finance has not been captured.

A small number of papers that also use the detailed financial information from the BEEPS dataset consider the demand in investigating access to credit. Muravyev et al. (2009) explain loans acceptance and control for loan applications in a robustness check, showing that female owners are less likely to obtain loans than male owners. The analysis by Brown et al. (2011)

\footnotetext{
${ }^{3}$ A detailed survey of approaches to measure financial frictions can be found in Gumpert (2012).
} 
provides a comprehensive examination of the firm and country characteristics that influence whether a firm needs a loan, applies for it and is successful with its application. Popov and Udell (2012) show that the financial health of banks influences the loan supply for firms. We contribute to the literature by constructing a direct measure of access to credit and evaluating first, whether the usage of credit is a suitable approximation for access to credit; and second, whether perception-based indicators provide a precise measurement of credit constraints.

The paper is organized as follows: Section 2 describes the data and the econometric specification. The results of the empirical analysis on the determinants of access to credit and the evaluation of the usage-approach and perception-based indicators are presented in Section 3 and Section 4 presents robustness checks. This is followed by some conclusions in Section 5.

\section{Data and Methodology}

\subsection{Data}

We use the Business Environment and Enterprise Performance Survey (BEEPS) collected jointly by the World Bank and the European Bank for Reconstruction and Development. The BEEPS assesses the environment for private enterprises and business development. The survey conducted in March and April 2005 entails the most detailed information on debt financing among all waves and thereby enables us to directly measure access to credit. ${ }^{4}$ It covers 27 countries in Eastern Europe and Central Asia. Depending on the size of the country, between 200 and 900 firms were interviewed. We exclude data from Uzbekistan, Tajikistan, Turkmenistan and Serbia as information on institutional characteristics is missing. We also leave out Turkey to focus on transition countries. So we ultimately analyze 5,762 firms in 23 countries, 14 countries from Central and Eastern Europe (Albania, Bosnia and Herzegovina, Bulgaria, Croatia, Czech Republic, Estonia, Macedonia, Hungary, Latvia, Lithuania, Poland, Romania, Slovakia and Slovenia) and nine countries from the former Soviet Union (Armenia, Azerbaijan, Belarus, Georgia, Kazakhstan, Kyrgyzstan, Moldova, Russia and Ukraine). Stratified random sampling ensures that the samples are representative in each country. Firms from both manufacturing and service sectors were included, whereby the sectoral composition in the sample is determined by the relative contribution of manufacturing

\footnotetext{
${ }^{4}$ Only the BEEPS 2005 wave provides information on the usage of credit and credit applications that both refer to the same time period. In the BEEPS 2009 wave information on the application for loans refers to the fiscal year 2007, while the usage information refers to past loans without time restrictions. Both pieces of information are necessary to to compare the usage and the access approach and should cover the same time period.
} 
and service sectors to domestic GDP. Firms that operate in sectors subject to government price regulation and prudential supervision (e.g. banking, electric power, rail transport, water and waste) were not included in the sample (see EBRD, 2005).

The questionnaire contains general firm characteristics and a detailed section on the financing of the firm. Information on the most recent loan is available and when loans are not used within a firm, additional information on the reasons are provided. In our sample, 47 percent of all firms currently have a loan. Among firms that do not use loans, about five percent were rejected while 93 percent did not apply for a loan. In two percent of all cases credit applications were still pending. Additionally, firms cite multiple reasons why they did not apply for a loan. The answers can be broadly divided into two categories. Firstly, some firms were discouraged from credit applications for reasons such as too high burdens in the application procedure, overly strict collateral requirements, excessively high interest rates or informal payments that have to be made to obtain a loan. Secondly, a firm may not have applied for a loan because it did not need one. In short, 36 percent of the non-applicants were discouraged from a credit application, while the major proportion of 64 percent had no need for bank financing. This differentiation is essential to identifying access to credit in the following analysis. Table 1 provides the descriptive statistic.

\section{[Table 1]}

\subsection{Measuring Access to Credit}

The detailed questionnaire on the financing of firms enables us to construct a direct measure of access to credit and to evaluate whether the usage of credit and perception-based indicators are suitable approximations for access to credit. For investigating access to credit it is essential to consider only firms that have demand for credit. To identify firms with credit demand, we make use of the above mentioned differentiation between rejected and discouraged firms and firms with no need for credit. We classify the following groups as having demand for credit:

a. Firms that are using loans,

b. Firms that have applied for a loan, but were rejected and

c. Firms that were discouraged from applying for credit.

A firm is classified as discouraged when it has not applied for a credit purely because it was discouraged from doing so, and not because it did not require credit. Accordingly, the binary 
variable demand equals 1 for the first three cases. It equals zero if the firm does not have a loan because it had no need for credit and therefore did not apply for one. ${ }^{5}$ Subsequently, to analyze access to credit we consider only firms which experienced demand. Firms that demand credit and have a loan are classified as having access to credit (a), while firms with credit demand that do not have a loan are classified as being credit constrained $(b, c)$. The latter group comprises of discouraged firms and firms that applied for a loan, but were rejected. The variable access therefore equals 1 if a firm has a loan and zero if a firm does not have a loan, although it does have credit demand. Hereby, we follow the literature on this topic and group firms that were rejected together with firms that were discouraged from applying (see e.g. Popov and Udell, 2012 for definitions for credit constraints of firms; Cox and Jappelli (1993) and Duca and Rosenthal (1993) for credit constraints of households).

\section{[Table 2]}

For the perception-based indicator firms were asked to evaluate whether access to financing in general, i.e. the financing available from banks, was problematic in terms of the operation and growth of their business. The variable perceived access varies from 1 "major obstacle" to 4 "no obstacle", such that a higher value signals a better access to finance.

As for the usage of credit, we construct the variable usage, which equals 1 if a firm has a loan and zero otherwise. This measure is equivalent to former studies that approximate access to credit by the usage of credit. Among firms without loans, this method does not differentiate between credit constrained firms (including rejected and discouraged firms) and firms that actually have no demand for credit.

\subsection{Regression Strategy}

In a first step we investigate the determinants of the direct measure of access to credit and estimate the following probit models

$$
\begin{aligned}
\text { access }_{i s c}= & \phi\left(\alpha_{0}+\alpha_{1}{\text { age } 0-7_{i s c}}+\alpha_{2} \text { age } 14_{i s c}+\alpha_{3} \text { foreign }_{\text {isc }}+\alpha_{4} \text { state-owned }_{i s c}\right. \\
& +\alpha_{5} \text { privatized }_{i s c}+\alpha_{6} \text { small }_{i s c}+\alpha_{7} \text { transparency }_{i s c} \\
& \left.+\alpha_{8} \text { profitability }_{i s c}+\alpha_{9} \text { capacit }_{i s c}+\eta_{s}+\lambda_{c}\right)
\end{aligned}
$$

\footnotetext{
${ }^{5}$ The number of firms with pending loan applications is very small. It is unclear whether firms will obtain access to loans, so we do not include them in our analysis.
} 
where $\phi$ denotes the standard normal cumulative distribution function and the indices $i, s$ and c indicate firm, sector and country, respectively. $\eta_{s}$ and $\lambda_{c}$ denote sector and country dummies.

In the probit estimation of access to credit we restrict our sample to firms that have credit demand. However, the selection into the demand group might not be random and unmeasured determinants could jointly influence the firm's demand for a loan and the probability of getting access to credit. If this unobserved heterogeneity is correlated with the covariates in the access estimation, the estimations suffer from an omitted variable bias. Therefore, we additionally control for potential selection bias by estimating a bivariate selection model that takes into account interdependencies between the selection and the outcome stage. We use a probit model with sample selection based on Heckman (1979). It implies binary outcomes for both stages. Under the assumption of a bivariate normal and independent error distribution, maximum likelihood estimation provides consistent estimators. We estimate

$$
\operatorname{Prob}(\text { access }=1 \mid \text { demand }=1, x)=\frac{1}{\phi(x \delta)} \int_{-x \delta}^{\infty} \phi\left[\frac{x_{1} \gamma+\rho \omega}{\left(1-\rho^{2}\right)^{1 / 2}}\right] * \phi(\omega) d \omega
$$

with

$$
\begin{aligned}
& \text { access }=1\left[x_{1} \beta_{+} \epsilon>0\right] \\
& =1\left[\beta_{0}+\beta_{1}{\text { age } 0-7_{i s c}}+\beta_{2} \text { age } 14+{ }_{i s c}+\beta_{3} \text { foreign }_{i s c}+\beta_{4} \text { state-owned }_{i s c}\right. \\
& +\beta_{5} \text { privatized }_{i s c}+\beta_{6} \text { small }_{i s c}+\beta_{7} \text { transparency }_{i s c}+\beta_{8} \text { profitability }_{i s c} \\
& \left.+\beta_{9} \text { capacity }_{i s c}+\beta_{s}+\lambda_{c}+\epsilon_{i}>0\right] \\
& \text { demand }=1[x \delta+\omega>0] \\
& =1\left[\gamma_{0}+\gamma_{1} \text { age } 0-7_{i s c}+\gamma_{2} \text { age } 14+{ }_{i s c}+\gamma_{3} \text { foreign }_{i s c}+\gamma_{4} \text { state-owned }{ }_{i s c}\right. \\
& +\gamma_{5} \text { privatized }_{i s c}+\gamma_{6} \text { small }_{i s c}+\gamma_{7} \text { transparency }{ }_{i s c}+\gamma_{8} \text { profitability }_{\text {isc }} \\
& +\gamma_{9} \text { capacity }_{i s c}+\gamma_{9} \text { perceived-competition }+\gamma_{10} \text { investment }+\eta_{s} \\
& \left.+\lambda_{c}+\omega_{i}>0\right]
\end{aligned}
$$

where access is the outcome and demand the selection equation. $\rho$ is the correlation between 
$\epsilon$ and $\omega .6$

For a robust identification additional exclusion restrictions are necessary, i.e. variables that generate nontrivial variation in the selection variable, but do not directly affect the outcome variable (Cameron and Trivedi, 2010). In our regression we include a firm's individual perception of competition as exclusion restriction. This measure from a firm's own perception has the advantage of measuring the firm-specific competition and capturing (unobserved) variation of firms within the same sector. ${ }^{7}$ The competitive environment of a firm should influence credit demand, because faced with greater competition, firms may invest more often in order to improve their position relative to other competitors and therefore may need external finance more often. However, banks base their decision to grant a loan mainly on hard information, and specifically on figures that are observable in the firm's balance sheet. For the assessment of the competitive environment, banks mainly use industry ratings that evaluate industries globally and disregard region- and firm-specific circumstances. ${ }^{8}$

Thus, after controlling for fixed differences on sector (and country) level, additional variation from the individual perception of competition should not have a direct impact on a bank's decision to grant loans. ${ }^{9}$ To measure the competitive environment, firms were asked what would happen if they raised the prices of their main product line or main line of services by ten percent in the domestic market. The variable perceived-competition takes the value 1 if they expected customers to continue to buy the same quantities, 2 if they were predicted to buy a slightly reduced quantity, 3 if they were expected to buy a much lower quantity, and lastly 4 if many buyers were forecast to switch and buy from the competitor instead. To directly measure the investments of a firm, we also include the dummy variable investment in the demand equation, which equals 1 if the firm has acquired a new production technology within the last 36 months.

In a second step we reestimate equation (1) for the dependent variables usage (probit regression) and the perception-based indicator perceived access (OLS regression) to evaluate

\footnotetext{
${ }^{6}$ A detailed derivation of the likelihood function for the probit model with sample selection can be found in Wooldridge (2002).

${ }^{7}$ E.g. Tang (2006) and Schmiele (2012) use similar measures to explain why firms exhibit different levels of innovation activities within the same product market.

${ }^{8}$ This assumption is confirmed in the guide of a development bank compiled for firms applying for loans at commercial banks. It gives firms advice on how to apply and provides explanations for bank behavior (LfA, 2009).

${ }^{9}$ Regressing access and usage on competition confirms the assumption that conditional on firm specific and macroeconomic characteristics, perceived competition does not affect access to credit, although it has a significant influence on the usage of credit.
} 
whether these approaches identify the same determinants of credit constraints.

Firm-Level Explanatory Variables. Judging by the policy debate and the existing evidence, there are several important firm-specific characteristics that may influence access to credit (see e.g. Beck et al. (2006) and Brown et al. (2011)). These include the size, age and ownership of the firm. With respect to size different effects interact. On the one hand, the banks' costs for conducting a credit evaluation do not vary a lot with the amount of the loan. Thus, smaller loans are less profitable for banks, which may therefore be reluctant to lend to larger firms. On the other hand, there is a diversification effect by granting many small loans. The dummy variable small controls for the size of a firm, it equals 1 if the number of employees is less than 50. For newly founded firms the information asymmetries faced by a creditor are most severe. Older firms already have a track record and can (ideally) show that they have always repaid on time. At the same time, the age of a firm should also influence credit demand. Depending on the stage of development of a firm, financial needs differ and so do the alternative sources of finance available. To measure the effect of age, we use dummy variables to take account of young firms (0 - 7years), transition firms (8-13 years) and pre-transition firms (14 years or more), that were established before 1991.

In transition countries, the ownership structure has some special features. After the demise of the socialist system all firms were basically state-owned. Since then many of the firms have been privatized with the aim of rendering them more efficient. From this point of view, privatized firms should be better debtors. However, if state-owned firms have a soft budget constraint, they will not fail and therefore the bank does not face a risk financing them. The effect of ownership structure is captured with the dummy variables private, privatized and state-owned. Furthermore we control for the nationality of a firm and include the dummy variable foreign, which equals 1 if the largest shareholder is a foreign company. Firms can try to reduce the information asymmetries faced by the investors by becoming more transparent, for instance, through reporting their balance-sheets according to international accounting standards and having them audited by a renowned auditing company. The variable transparency takes the value 0 if a firm neither uses international accounting standards nor external audits; it takes the value 1 if at least one of them is used and the value 2 if both are used. ${ }^{10}$ Moreover, the chance of being granted a loan depends on the firm's default risk.

\footnotetext{
${ }^{10}$ This measure is based on Brown et al. (2009). The degree of transparency is determined by firms' choices
} 
We capture this risk by the profitability of a firm. The dummy variable profitability equals 1 if the firm realized profits in 2003 and zero otherwise. The utilization capacity should also indicate the order situation and approximate the firm's likelihood of success. The variable capacity measures the degree of output in comparison with the maximum possible output (in percentage).

The sector in which a firm operates plays an important role. Depending on the nature of the firm's business, the need for financing might differ substantially. For instance, the size of investments is much higher in manufacturing than in retail. Thus, the demand for credit might strongly depend on the firm's sector. However, we expect that access to loans depends on firm-specific, rather than on sector-specific factors. We control for differences in sector characteristics by using dummy variables that are equal to 1 if over 50 percent of a company' sales comes from this sector. ${ }^{11}$ The sectors are mining and quarrying (sector 1$)$, construction (sector 2), manufacturing (sector 3), wholesale, retail and repairs (sector 4), real-estate, renting and business services (sector 5), hotels and restaurants (sector 6) and others (sector 7). Table 3 summarizes the firm-level explanatory variables.

\section{[Table 3]}

Country-Level Explanatory Variables. To gain further insights into macroeconomic determinants, we additionally replace the country dummies $\lambda_{c}$ in all specifications with explanatory variables at the country-level that are expected to influence access to credit. The legal framework is of particular importance, since it shapes the credit contracts that can potentially be designed through two channels. The first channel is the protection of creditor rights as codified in the law. The better creditor rights are protected, the more likely banks are willing to provide loans (La Porta et al., 1998). The second channel is how well the protection of creditor rights is indeed enforced (Pistor et al., 2000). We capture the first channel through an index of creditor rights constructed by the World Bank. It measures the degree to which collateral and bankruptcy laws protect the right of borrowers and lenders and ranges between 1 and 10 . A higher score facilitates lending and therefore leads to better access to credit. For the second

within regulatory limits. However, in the following analysis it is treated as an exogenous variable, referring to robustness checks provided by Brown et al. (2009). Using the same measure of transparency, they control for potential endogeneity using instrumental variables estimations and show that analysis of cost and usage of credit using BEEPS data do not change.

${ }^{11}$ The majority of the firms operate in a single sector. We additionally construct a sector measure that takes into account where the maximum proportion of sales comes from, which does not change the results. 
channel we use the effectiveness of legal institutions as measured by the days it takes to enforce a contract (enforcement). Credit markets are subject to substantial problems of asymmetric information, which are most severe in emerging markets. Information sharing devices such as credit registries are an important mechanism for reducing information asymmetries by providing information on, for instance, whether a firm has defaulted on a loan previously. Thus, their existence should make access easier, particularly for more opaque firms. ${ }^{12}$ Here we use an index developed by Brown et al. (2009). This index measures the presence and structure of public credit registries and private credit bureaus. The value ranges from 1 to 5 , the more detailed the information provided is and the longer the registry has existed, the higher the scale.

The effect of foreign bank presence on access to credit is controversial. On the one hand, foreign banks bring expertise and capital into the host market, which can improve access to credit (particularly for larger firms, as Giannetti and Ongena (2009) show). On the other hand, it is argued that foreign banks might focus on particularly lucrative projects, which are easily identifiable because they are transparent. As a result, access to credit might become more difficult (Detragiache et al., 2006 and Gormley, 2010). However, foreign bank entry also affects the behavior of domestic banks; they may start lending to more opaque firms and thereby benefit all firms (Dell' Arricia and Marquez, 2004, Giannetti and Ongena, 2009). We capture the presence of foreign banks by the market share of foreign-owned banks (among all bank assets). Moreover, we use the income level measured by the log of the GDP per capita $(\log G D P p c)$ and inflation as explanatory variables and include a measure of bank concentration. Table 4 summarizes the country-level explanatory variables. For all country-level variables we use average values for the years 2001-2003, despite creditor rights and enforcement (2005 values, earlier values are not available). The definitions and data sources of the explanatory variables can be found in Table A.1 in the Appendix.

[Table 4]

\footnotetext{
${ }^{12}$ There is a rich body of theoretical literature on the effects of information sharing on the behavior of borrowers and ultimately on the credit market (for a summary see Brown et al., 2009). Information sharing does not have positive effects on access to credit in all models. The effects depend crucially on the incentive problem specified in the model.
} 


\subsection{Descriptive Statistics}

In contrast to the access approach, the use approach does not take into account differences in firm-specific credit demand. Therefore, within the no use group no differentiation is made between firms that have credit demand (and are considered to be credit constrained) and firms without credit demand. However, these types of firms may differ systematically and aggregating them into one group might not make it possible to draw conclusions regarding credit constraints. To evaluate the grade of heterogeneity, we compare both groups with regard to differences in average firm characteristics. Among firms that do not have loans, the majority has no demand for credit (61 percent), while 39 percent are credit constrained. A two-sample t-test for continuous variables (and a proportion test for binary variables) shows that the differences in means are significantly different from zero for most firm characteristics (Table 5, panel A). Firms that experience credit constraints (demand group) are significantly more often young firms and less often foreign or state-owned. Firms without demand are, on average, more transparent and more often profitable than credit constrained firms. In short, the heterogeneity among firms within the "no usage" group is large and the considerable fraction of firms with no credit demand indicates that the usage approach might provide misleading conclusions on credit constraints.

In the access approach demand is directly taken into account, whereby self-selection might be present. Comparing differences in average firm characteristics of firms with and without demand for credit in the whole sample can provide a first hint as to selection into the demand group. We find that both groups differ significantly in ownership, size and transparency (Table 5, panel B). Firms with credit demand are less often foreign and state-owned, but more often privately-owned and privatized. Among firms with credit demand, 68 percent are small compared to 73 percent in the no-demand group. The comparison in means provides initial evidence that the selection into the demand group might not be random.

\section{[Table 5]}

The distribution of perceived access among different groups is presented in Table 6. The average perception is 2.715 , whereby a higher value indicates better access to credit. It is noticeable that the perception of access is better among firms without credit demand (3.135) than for firms with demand (2.516). This strengthens our assumption that firms without credit demand state that they experience no obstacle regarding access to credit. Furthermore, firms 
that do not use loans have a better perception than firms that have access to loans ( 2.756 versus 2.670), which indicates that firms without a loan are not necessarily credit constrained.

[Table 6]

\section{Results}

\subsection{Access to Credit}

In this section we present the regressions for access to credit. Table 7 summarizes the estimation results. The first two columns present the basic probit estimations. The first specification investigates firm-specific factors (Column 1) and additionally controls for sector and country fixed effects by including sector and country dummies. The second specification replaces the country dummies with explanatory variables at the country level. We find that small firms and state-owned firms are less likely to get access to loans, while transparent and profitable firms are more likely to have access. Young firms (0-7 years) have a higher probability of being financial constrained in comparison to established firms (8 - 13 years), while firms that were founded before transition do not differ in their access to credit. With respect to sector dummies, no sector-specific differences can be found except for the category others that cannot be further specified. The results for the firm-specific effects are robust and do not change when country-specific variables are added. We find that better creditor rights have a positive effect on access to credit.

Column three and four present the probit estimations with sample selection. For both specifications the Wald test of independent equations rejects the null hypothesis of uncorrelated error terms at a one percent significance level, such that the selection into credit demand is not random. In the selection equation, we find that small firms have a 6 percentage point lower probability of demanding a loan. This suggest that small firms might use internal financing sources more often or invest less than large firms. In contrast, a positive marginal effect is found for young firms, but this is not significant (p-value 0.123 and 0.122 ). This weakly indicates that young ventures may rely more on debt financing than established firms, possibly for the reason that they have not yet generated sufficient internal funds or that other financing sources, which are available to older companies, are less suitable. Capacity, which approximates how successfully a firm attracts external orders, is significantly negative, indicating that more successful firm less often rely on debt financing. Foreign-owned firms 
have a 13 percentage lower probability of demanding a loan. An explanation could be that foreign-owned companies might have access to the internal capital markets of global holding companies and therefore rely less intensely on the host country's credit markets. Since we simultaneously control for profitability, we should be able to separate this effect from the second possible channel that foreign investors select the most profitable firms. However, not only the availability of internal sources and alternative financing sources affect the probability of credit demand, investments and competition are also found to be relevant. Firms that have invested in a new production technology and those facing more competition are more likely to demand credit. Additionally, state-owned firms are significantly less likely to demand credit than privately-owned firms.

After controlling for firm-level explanatory variables, sector-specific differences in credit demand are still present. Firms in all sectors except construction and manufacturing are less likely to have demand for credit than firms in the base sector mining and quarrying. When including explanatory variables at the country-level, the firm-level results remain mostly unchanged, although we find only inflation to have a significant coefficient. Firms that are located in countries with a higher inflation rate have, on average, a higher demand for credit financing.

In the outcome equation the results for the firm-specific variables are quite similar to the probit results, despite some important differences. In contrast to the basic probit regressions, foreign-owned companies have significantly better access to credit after controlling for selection into the demand group. Due to their lower demand, the better access enjoyed by foreign-owned firms is not identified in the basic probit regressions since both effects run in different directions and might cancel out. The same pattern can be observed for capacity. Regarding state-owned companies, the financial constraints identified in the probit regressions become insignificant when controlling for the lower demand of state-owned companies. Similar to the basic probit regression, better creditor rights are associated with significantly better access to credit when controlling for the selection into demand.

[Table 7]

\subsection{Usage of Credit}

The aim of our study is to investigate whether the usage of credit is a suitable proxy for access to credit when information on demand is not available. Therefore we estimate probit 
regressions to identify the determinants affecting the usage of credit without considering differences in credit demand and compare the results between both approaches. Table 8 presents the estimation results.

\section{[Table 8]}

The estimated marginal effects differ substantially from those estimated in the access approach. In terms of age we find no credit constraints on young companies, as identified in the access approach. Here, the higher demand and the poorer access to credit enjoyed by young companies are not disentangled and the resulting coefficient is not significant. Foreign-owned companies have a significantly lower usage of credit. Interpreting a lower usage of credit in terms of credit constraints would be misleading. In the access estimations foreign-owned companies are found to have a lower demand for credits, but conditional on demand they have a better access to credit. This is also similar for state-owned companies, which have a significantly lower usage due to lower demand, although they have no worse access to credit compared to private companies. Analogously misleading interpretations would also be drawn for sector-specific effects. In the usage approach we observe that many sectors have a significantly lower usage of credits, which is not due to sector-specific credit constraints, but can be explained by differences in demand. This suggests that sector-specific programs to improve access, such as public guarantees for loans to particular industries, would not reach the really financially constrained firms and therefore may be inefficient. With respect to country-level variables we find the same determinants on country-level. Better creditor rights, which were found to have a positive effect on the access to credit, do also significantly increase the usage of credits.

In terms of size, transparency and profitability, we find significant marginal effects with the same sign as in the access approach. However, differences occur in the magnitude of the estimated marginal effects. For small firms both approaches identify a higher probability of being financially constrained. In the access equation the probability of being financially constrained rises by 13.3 percent if a firm is small, compared to 20.3 percent in the usage equation. The usage approach overestimates the financial constraints of small firms, since it does not take into account their lower credit demand. With respect to transparency and profitability, where we have found less strong demand effects, the usage approach obtains very similar results. 
Statistical Comparison. The comparisons of the access and usage estimations already indicate that the identified determinants differ between both approaches. We investigate how systematic these differences are and most importantly, whether they are statistically significant. To draw statistical inference on the differences between the usage and the access approach, we perform a bootstrapped version of the Hausman test following Cameron and Trivedi (2010). This test compares the entire vectors of coefficients resulting from two different estimations and tests the null hypothesis of equal coefficients. ${ }^{13}$

Table 9 summarizes the bootstrap results for the differences in coefficients. Column 1 and 2 present the difference in estimated coefficients, the bootstrapped standard errors of the difference are in parenthesis. The test confirms the differences in age (for young companies), state- and foreign- ownership to be statistically significant. In the basic regressions the usage approach exhibited similar coefficient estimates in sign and magnitude for a firm's transparency and profitability. The bootstrap Hausman test indicates that, in the usage specification, the coefficient for size is significantly larger, while the coefficients for transparency and profitability are significantly smaller than in the access approach. Interpreting the usage of credits in terms of access to credit would therefore underestimate the credit constraints of small firms. At the same time the usage approach underestimates the better access to credit enjoyed by transparent and profitable firms.

\section{[Table 9]}

Graphical Comparison. A graphical comparison of access and usage can help to gain insights how systematic the underlying differences between both approaches are. In the estimation results the firm-level explanatory variables for foreign ownership and age were found to differ significantly between the usage and the access regressions. Both variables were additionally sampled as continuous variables and allow separately nonparametric locally weighted regressions for the dependent variables demand, access and usage (Figure 1). We find a concave relationship between age and the usage of credits. For firms that are older than 60 years in particular, we observe a decreasing usage of credit. In terms of the access

\footnotetext{
${ }^{13}$ The standard Hausman test requires one of the estimators to be fully efficient. This assumption is needed to simplify the calculation of $\operatorname{Var}(\hat{\theta}-\tilde{\theta})$ in the Hausman test statistic $H=(\hat{\theta}-\tilde{\theta})^{\prime} \hat{\operatorname{Var}}(\hat{\theta}-\tilde{\theta})(\hat{\theta}-\tilde{\theta})$. $\operatorname{Var}(\hat{\theta}-\tilde{\theta})$ simplifies to $\operatorname{Var}(\hat{\theta})-\operatorname{Var}(\tilde{\theta})$ if $\theta$ is fully efficient. In our analysis both models are not efficient since we have reasons to assume that the data is clustered on country level and necessarily have to use cluster robust standard errors. Bootstrapping enables estimating $\operatorname{Var}(\hat{\theta}-\tilde{\theta})$ without the need to assume full efficiency of one estimator (see Cameron and Trivedi, 2010, p. 443).
} 
to credit, however, a positive relationship with a strongly increasing access to credit for older firms is found, while the demand for credit decreases with firm age. The concave relationship of usage captures the decreasing credit demand of older firms and shows that supply and demand effects are not disentangled in the usage approach. A similar pattern can be observed for foreign ownership. While the demand for credits decreases as the share of foreign investors rises, access to credit increases. The usage of credits reflects both - the supply and the demand effect. It increases in foreign ownership until a share of 50 percent is reached and subsequently decreases.

[Figure 1 and 2]

\subsection{Perception-based Indicator}

Table 10 presents the regression results for the perception-based indicator. The determinants of the perceived access largely coincide with the identified determinants of access to loans (Section 3.1). For size, transparency and profitability we find highly significant effects similar to the access and usage approaches - larger firms, more transparent and profitable firms have better access to credit. The credit constraints of young companies are also identified, however the effect is less robust. In contrast to the usage approach, the better access to credit of foreign owned firms and successful firms in terms of the capacity situation is identified here - without using information on credit demand. Furthermore, we find that firms in countries with higher GDP per capita have a significantly better perception of access to credit, while higher inflation rates are associated with a worse perceived access to credit. Interestingly, while the enforcement of contracts has no significant effect on access to credit, it influences the perception of access to credit and a weaker enforcement (more days to resolve a dispute) is associated with worse perceived access to credit.

We use the comprehensive information on credit demand to further analyse whether the identified determinants of the perceived access to credit differ with a firm's credit demand. The regressions are estimated separately for the subsample of firms with credit demand (Columns 3-4) and firms without credit demand (Columns 5-6). Among firms with demand for credit the results are highly similar to the results from the whole sample of firms. We additionally find firms that were founded before the transition process to have a significantly worse perception of access to credit compared to firms founded during transition, which has not been found in the access and usage approach. In the sample of firms without credit demand, we found hardly 
any significant determinants, which indicates that the results on the perception of access to credit are mainly driven by firms with credit demand. However, the effects are strong enough to persist when pooling all firms and ignoring differences in demand, although the fraction of firms without demand is high.

To summarize, the perception of access to credit identifies the same firm-level determinants as the direct measurement of access to credit, even if information on credit demand is not available. It therefore seems to constitute a much better measurement of access to credit than approximations by usage. However, the increase in R-square from 0.08 to 0.10 (despite the drop of 32 percent in observations) indicates that the precision of the estimations can be increased when additional information on credit demand is available.

\section{Sensitivity Tests}

\subsection{Assumption of Joint Normality}

The maximum likelihood estimation of the binary response model with sample selection requires the assumption of a bivariate normal error distribution. This assumption might be too strong. As a robustness check we estimate access to credit with a linear Heckman two-step procedure that includes the inverse-mills ratio as an additionally explanatory variable. The Heckman two-step estimator relies on a weaker distributional assumption of univariate normality and is expected to be more robust (Cameron and Trivedi, 2010). However, if bivariate normality is fulfilled, the maximum likelihood estimator is the more efficient estimator. $^{14}$ Table A.2 shows that the estimation results are very stable. The selection into demand remains significant and the signs and significant levels of most coefficients do not change either.

\subsection{Assumption of Exogeneity}

So far we have assumed that the explanatory variables are exogenous. However, it could be questionable whether this assumption holds true for profitability. The availability of credit could (reversely) affect the profitability of a firm. To evaluate whether exogeneity of profitability is critical, we estimate instrumental-variables (IV) regressions. This robustness check allows us to evaluate the severity of a potential endogeneity problem by comparing

\footnotetext{
${ }^{14}$ A detailed theoretical discussion can be found in Cameron and Trivedi (2005).
} 
the baseline regressions with and without IV corrections. We instrument the profitability of a single firm with the competitors' average profitability. Competitors are defined as firms located in the same industry within the same country. The idea is that firms in the same industry within a country face a very similar competitive surrounding, such that the individual profitability of a firm should be sufficiently correlated with the average profitability of the particular industry in a particular country. At the same time, the average profitability of the other firms should not directly affect a single firm's likelihood of gaining access to credit. ${ }^{15}$ We estimate linear IV regressions, which require fewer distributional assumptions than binary outcome models. ${ }^{16}$ The results can be found in Table A.3. They are very similar to the identified determinants of access to credit and usage of credit.

\subsection{Standard Errors Clustered on Industry-Country-Level}

The standard errors in the baseline regressions are clustered at the country-level for 23 different country clusters. Although this might be a sufficiently large number of clusters, the underlying assumption for calculating cluster-robust standard errors requires the number of clusters to go to infinity. To assess whether this assumption is problematic in our regressions, we reestimate the baseline regressions with standard errors corrected on industry-country level. Hereby the number of clusters increases to 154. Correlations in errors of firms within the same industry in one country are taken into account, while inter-industry correlations within one country cannot be captured with this clustering structure. Table A.4 summarizes the results. The standard errors of the firm-level coefficients are unaffected. The results for the country specific determinants are basically similar. In the probit model with selection, foreign banks and enforcement have a significant positive coefficient (at the 10 percent level) and creditor rights keeps a significant positive coefficient. This indicates that our baseline standard error adjustment on country-level potentially overestimates the size of the standard errors.

\footnotetext{
${ }^{15}$ This type of instrumentation strategy has been used e.g. in Desai et al. (2006) and Gumpert et al. (2011). Note that this approach does not allow to include sector dummies.

${ }^{16}$ We disregard the selection problem here, as estimations with endogenous explanatory variables in binary response models with sample selection are not applicable yet and an important area of future research (Wooldridge, 2002, p.814).
} 


\section{Conclusions}

In this paper we develop a direct measurement of access to credit and investigate how precise different approximative measurements are in predicting credit constraints. This evaluation is of particular importance as direct measurements for access to credit, which are based on information on a firm's demand for credit, are often not available when using balance sheet data and are often missing in survey data. As a consequence, access to credit often has to be approximated by measurements based either on the usage of credit or on perception-based indicators, which do not take into account a firm's demand for credit. Not differentiating between these types of firms might aggravate the identification of financial constraints, as our main results show.

First, in investigating access to credit, we find that the selection into credit demand is not random and firms do self-select themselves. Not controlling for this selection can lead to biased estimations, particularly for determinants that affect demand and access in opposing directions. The effects may offset each other and coefficients are not significantly different from zero in estimating access to credit (e.g. coefficient for foreign-firms or capacity) or have the wrong sign when the effect of demand dominates the access effect (e.g. coefficient for state-owned firms), such that firms with a lower demand can appear to be credit constrained.

Second, the comparison of different approximative measurements of access to credit shows that the usage of credit does not allow to draw precise conclusions on credit constraints. We find considerable differences in the identified determinants of usage and access that can be explained by differences in a firm's demand for credit. Interpreting the usage of credit in terms of access can both under- and overestimate restricted access, depending on the direction of the demand effect. However, the comparison between the direct access approach and the perception-based indicator shows that these indicators are able to identify firm-level determinants of restricted access, even when information on demand is not available. Thus, our analysis suggests that perception-based indicators provide a relatively good measurement for restricted access when information on credit demand is missing, and are better suited than measurements based on the usage of credit.

With regard to future survey design for investigating access to finance our results stress the importance of including questions on the demand for external finance in questionnaires to be able to directly identify access to finance. Thereby it is of particular importance that information on demand and usage can be clearly matched, i.e. they should refer to the same 
time period (e.g. the previous fiscal year). Information on the application is not sufficient to identify financial demand. Firms can be discouraged from applying for several reasons, which should be considered in the survey design. To capture potential selection bias, suitable exclusion restrictions for the selection into demand should be considered beforehand in the list of questions. Furthermore, our analysis has proved perception-based indicators to be valuable approximative measures. However, to increase their precision, we recommend that firms should be likewise requested to give information on their financial need when setting up the questionnaire. With respect to future research, better information on a firms' creditworthiness from matched balance-sheet data or additional questionnaire information on the necessary balance-sheet items would significantly improve research on access to finance. 


\section{References}

Beck, T., Demirgüç-Kunt, A., 2008. Access to finance: An unfinished agenda. The World Bank Economic Review 22 (3), 383-396.

Beck, T., Demirgüç-Kunt, A., 2009. Financial institutions and markets across countries and over time: Data and analysis. World Bank Policy Research Working Paper No. 4943.

Beck, T., Demirgüç-Kunt, A., Laeven, L., Maksimovic, V., 2006. The determinants of financing obstacles. Journal of International Money and Finance 25 (6), 932 - 952.

Beck, T., Levine, R., Loayza, N., 2000. Finance and the sources of growth. Journal of Financial Economics 58, 261-300.

Brown, M., Jappelli, T., Pagano, M., 2009. Information sharing and credit: Firm-level evidence from transition countries. Journal of Financial Intermediation 18 (1), 151-172.

Brown, M., Ongena, S., Popov, A., Yeşin, P., 2011. Who needs credit and who gets credit in eastern europe? Economic Policy 26 (65), 93-130.

Cameron, C., Trivedi, P., 2005. Methods and Application. Cambridge University Press, New York, USA.

Cameron, C., Trivedi, P., 2010. Microeconometrics Using Stata. Stata Press, Texas, USA.

Campello, M., Graham, J. R., Harvey, C. R., 2010. Real effect of financial constraints: Evidence from the financial crisis. Journal of Financial Economics 97 (3), 470-487.

Cox, D., Jappelli, T., 1993. The effect of borrowing constraints on consumer liabilities. Journal of Money, Banking and Credit 25, 197-213.

Dell' Arricia, G., Marquez, R., 2004. Information and bank credit allocation. Journal of Financial Economics 72 (1), 185-21.

Desai, M. A., Foley, C. F., Hines, J. R., 2006. The demand for tax haven operations. Journal of Public Economics 90 (3), 513-531.

Detragiache, E., Tressel, T., Gupta, P., 2006. Foreign banks in poor countries: Theory and evidence. Journal of Finance 63 (5), 2123-2160. 
Duca, J. V., Rosenthal, S. S., 1993. Borrowing constraints, household debt, and racial discrimination in loan markets. Journal of Financial Intermediation 3 (1), 77-103.

EBRD, 2005. The business environment and enterprise performance survey (BEEPS) 2005: A brief report on observations, experiences and methodology from the survey. URL http://www .ebrd.com/downloads/research/economics/beeps05r.pdf

Fazzari, S., Hubbard, R. G., Petersen, B., 1988. Financing constraints and corporate investment. Brookings Papers on Economic Activity, 141-195.

Giannetti, M., Ongena, S., 2009. Financial integration and firm performance: Evidence from foreign bank entry in emerging markets. Review of Finance 13 (2), 181-223.

Gormley, T. A., 2010. The impact of foreign bank entry in emerging markets: Evidence from india. Journal of Financial Intermediation 19 (1), 26-51.

Gumpert, A., 2012. Measuring financial constraints: A survey of approaches, mimeo.

Gumpert, A., Hines, J. R., Schnitzer, M., 2011. The use of tax havens in exemption regimes. NBER Working Paper 17644.

Heckman, J. J., 1979. Sample selection bias as a specification error. Econometrica 47 (1), pp. 153-161.

Kaplan, S., Zingales, L., 1997. Do financing constraints explain why investment is correlated with cash flow? Quarterly Journal of Economics 112, 169-215.

Kaplan, S., Zingales, L., 2000. Investment-cash flow sensitivities are not valid measures of financing constraints. Quarterly Journal of Economics 115, 707-712.

Karlan, D., Murduch, J., 2009. Handbook of Development Economics, forthcoming Edition. Vol. 5.

La Porta, R., Lopez de Silanes, F., Shleifer, A., Vishny, R., 1998. Law and finance. Journal of Political Economy 106, 1113-1155.

LfA, 2009. Lfa Förderbank Bayern, Leitfaden für den Bankenbesuch, April 2009. URL http://www.lfa.de/website/downloads/broschueren/b_leitfaden/b_leitfaden.pdf 
Muravyev, A., Talavera, O., Schäfer, D., 2009. Entrepreneurs' gender and financial constraints: Evidence from international data. Journal of Comparative Economics 37 (2), 270-286.

OECD, 2011. The impact of the financial crisis on the insurance sector and policy responses. Policy Issues in Insurance 13, OECD Publishing.

Pistor, K., Raiser, M., Gelfer, S., 2000. Law and finance in transition countries. Economics of Transition 8, 325-68.

Popov, A., Udell, G. F., 2012. Cross-border banking, credit access, and the financial crisis. Journal of International Economics 87 (1), 147 - 161.

Rajan, R., Zingales, L., 1998. Financial dependence and growth. American Economic Review 88 (3), 559-86.

Safavian, M., Sharma, S., 2007. When do creditor rights work? Journal of Comparative Economics 35 (3), 484-508.

Schmiele, A., 2012. Drivers for international innovation activities in developed and emerging countries. The Journal of Technology Transfer 37 (1), 98-123.

Tang, J., 2006. Competition and innovation behaviour. Research Policy 35 (1), 68 - 82.

Wooldridge, 2002. Econometric Analysis of Cross Section and Panel Data. Vol. Econometric Analysis of Cross Section and Panel Data. MIT Press.

World Bank, 2006. Doing Business 2006. World Bank, Washington D.C. 
Figure 1: Locally weighted regressions
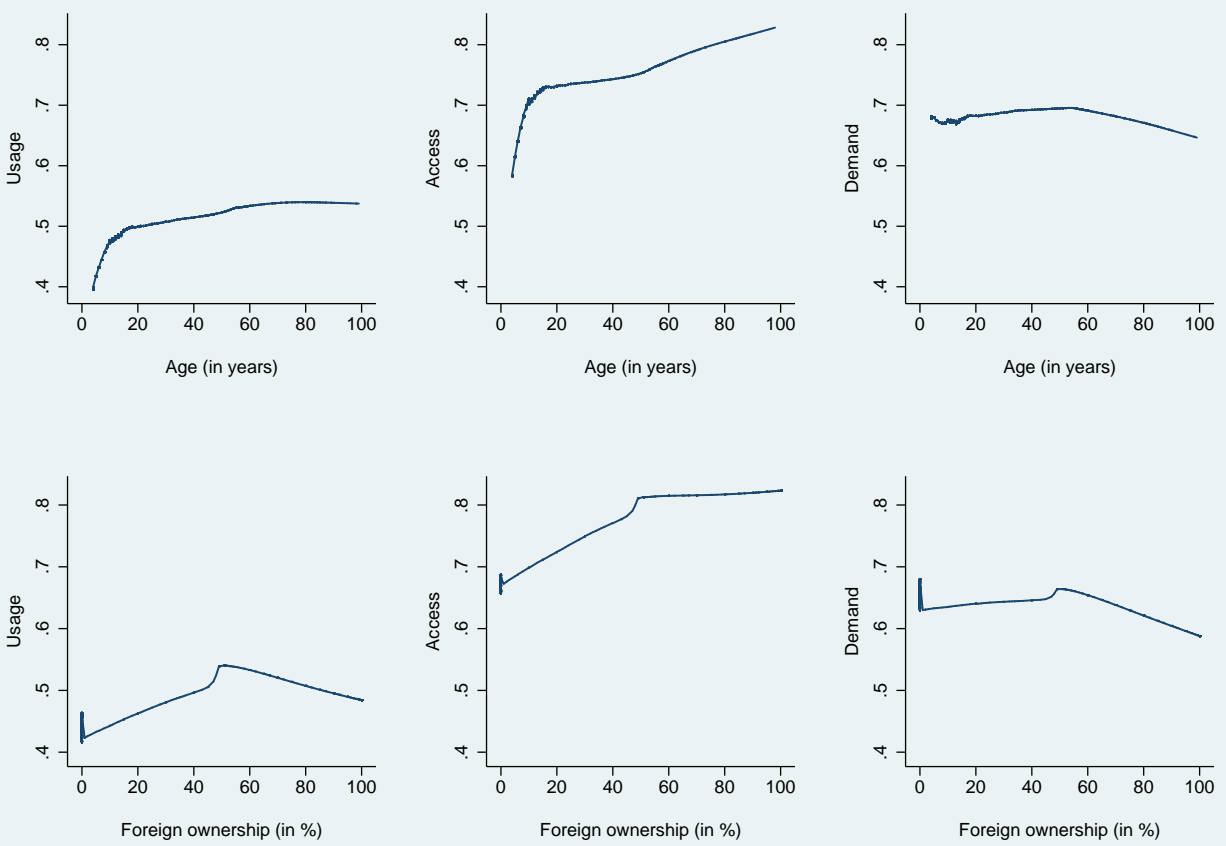
Table 1: Identifying access to loans

\begin{tabular}{lrr}
\hline \hline Does the firm have a loan? & Freq. & Percent \\
\hline Yes & 2,695 & 46.77 \\
No & 3,067 & 53.23 \\
\hline Total & 5,762 & 100 \\
& & \\
If the firm does not have a loan, what was the reason? & Freq. & Percent \\
\hline Firm did not apply for a loan & 2,853 & 93.02 \\
Application was turned down & 141 & 4.60 \\
Application for the loan is still pending & 73 & 2.38 \\
\hline Total & 3,067 & 100 \\
& & \\
If the firm did not apply, what were the main reasons? & Freq. & Percent \\
A: Multiple answers & 1,830 & 46.27 \\
\hline Does not need a loan & 529 & 13.38 \\
Application procedure too burdensome & 564 & 14.26 \\
Collateral requirements too strict & 786 & 19.87 \\
Interest rates too high & 80 & 2.02 \\
Informal payments necessary to get bank loans & 104 & 2.63 \\
Did not think it would be approved & 62 & 1.57 \\
Others & 4,416 & 100 \\
\hline Total & & \\
& Freq. & Percent \\
B: Consolidated answers & 1,830 & 64.14 \\
No need (at least one answer is "does not need a loan") & 1,023 & 35.86 \\
Discouraged (none of the answers is "does not need a loan") & 2,853 & 100 \\
\hline Total & & \\
\hline \hline
\end{tabular}

Table 2: Coding of the dependent variables

\begin{tabular}{lcccrr}
\hline \hline Categories & Usage & Demand & Access & Freq. & Percent \\
\hline Firm has a loan & 1 & 1 & 1 & 2,695 & 47.37 \\
No loan, because application turned down & 0 & 1 & 0 & 141 & 2.48 \\
No loan, because discouraged from applying & 0 & 1 & 0 & 1,023 & 17.98 \\
No loan, because no need & 0 & 0 & - & 1,830 & 32.17 \\
\hline
\end{tabular}


Table 3: Firm-level explanatory variables

Notes: Definitions and sources of the explanatory variables are summarized in Table A.1.

\begin{tabular}{|c|c|c|c|c|c|c|c|c|c|c|c|c|}
\hline Country & $\begin{array}{c}\text { Age } \\
\text { (in years) }\end{array}$ & Age 0-7 & Age $14+$ & Foreign & $\begin{array}{c}\text { State- } \\
\text { Owned }\end{array}$ & Privatized & Small & Transparency & Profitability & Capacity & Investment & $\begin{array}{c}\text { Perceived } \\
\text { Competition }\end{array}$ \\
\hline Albania & 10.54 & 0.38 & 0.08 & 0.04 & 0.07 & 0.06 & 0.77 & 0.94 & 0.92 & 76.19 & 0.42 & 2.48 \\
\hline Armenia & 14.64 & 0.45 & 0.30 & 0.07 & 0.05 & 0.30 & 0.79 & 0.72 & 0.98 & 81.93 & 0.55 & 2.50 \\
\hline Azerbaijan & 12.24 & 0.40 & 0.19 & 0.16 & 0.13 & 0.05 & 0.56 & 0.92 & 0.99 & 86.29 & 0.74 & 2.44 \\
\hline Belarus & 12.88 & 0.35 & 0.21 & 0.10 & 0.12 & 0.03 & 0.72 & 0.47 & 0.87 & 80.84 & 0.28 & 2.48 \\
\hline Bosnia & 20.17 & 0.31 & 0.33 & 0.14 & 0.11 & 0.15 & 0.54 & 0.70 & 0.80 & 82.24 & 0.48 & 2.58 \\
\hline Bulgaria & 17.91 & 0.20 & 0.35 & 0.11 & 0.09 & 0.15 & 0.71 & 0.73 & 0.80 & 85.11 & 0.29 & 2.59 \\
\hline Croatia & 24.30 & 0.09 & 0.50 & 0.11 & 0.10 & 0.23 & 0.61 & 1.15 & 0.95 & 85.47 & 0.47 & 2.52 \\
\hline Czech Republic & 12.89 & 0.28 & 0.26 & 0.10 & 0.07 & 0.08 & 0.76 & 0.45 & 0.92 & 86.78 & 0.25 & 2.41 \\
\hline Estonia & 14.68 & 0.17 & 0.30 & 0.16 & 0.10 & 0.12 & 0.66 & 1.67 & 0.90 & 81.88 & 0.20 & 2.56 \\
\hline Georgia & 20.97 & 0.39 & 0.35 & 0.09 & 0.11 & 0.30 & 0.73 & 1.19 & 0.78 & 77.02 & 0.34 & 2.61 \\
\hline Hungary & 16.08 & 0.23 & 0.39 & 0.12 & 0.05 & 0.11 & 0.70 & 0.89 & 0.85 & 80.66 & 0.16 & 2.90 \\
\hline Kazakhstan & 10.26 & 0.50 & 0.15 & 0.06 & 0.05 & 0.20 & 0.72 & 0.44 & 0.88 & 85.97 & 0.34 & 2.38 \\
\hline Kyrgyzstan & 20.41 & 0.24 & 0.41 & 0.15 & 0.11 & 0.37 & 0.62 & 0.90 & 0.79 & 76.75 & 0.49 & 2.62 \\
\hline Latvia & 15.45 & 0.37 & 0.19 & 0.08 & 0.11 & 0.08 & 0.77 & 0.83 & 0.68 & 77.85 & 0.29 & 2.34 \\
\hline Lithuania & 13.83 & 0.21 & 0.22 & 0.09 & 0.09 & 0.14 & 0.70 & 0.64 & 0.75 & 82.37 & 0.32 & 2.90 \\
\hline Macedonia & 20.97 & 0.25 & 0.41 & 0.10 & 0.12 & 0.19 & 0.69 & 0.53 & 0.80 & 80.92 & 0.31 & 2.67 \\
\hline Moldova & 11.74 & 0.32 & 0.16 & 0.09 & 0.06 & 0.22 & 0.66 & 0.22 & 0.63 & 78.48 & 0.40 & 2.46 \\
\hline Poland & 17.83 & 0.21 & 0.48 & 0.06 & 0.06 & 0.07 & 0.73 & 0.46 & 0.87 & 83.86 & 0.37 & 2.85 \\
\hline Romania & 16.39 & 0.20 & 0.30 & 0.08 & 0.06 & 0.12 & 0.65 & 0.60 & 0.83 & 86.66 & 0.41 & 2.34 \\
\hline Russia & 12.86 & 0.43 & 0.20 & 0.10 & 0.10 & 0.10 & 0.63 & 0.50 & 0.88 & 84.01 & 0.35 & 2.33 \\
\hline Slovakia & 13.87 & 0.23 & 0.30 & 0.13 & 0.07 & 0.08 & 0.71 & 0.67 & 0.86 & 87.95 & 0.23 & 2.66 \\
\hline Slovenia & 24.39 & 0.09 & 0.61 & 0.07 & 0.11 & 0.24 & 0.68 & 0.64 & 0.76 & 87.01 & 0.34 & 2.36 \\
\hline Ukraine & 15.08 & 0.38 & 0.24 & 0.10 & 0.07 & 0.15 & 0.70 & 0.50 & 0.83 & 76.46 & 0.33 & 2.32 \\
\hline Total & 15.48 & 0.30 & 0.30 & 0.09 & 0.08 & 0.14 & 0.70 & 0.63 & 0.85 & 82.61 & 0.35 & 2.54 \\
\hline
\end{tabular}


Table 4: Country-level explanatory variables

Notes: Definitions and sources of the explanatory variables are summarized in Table A.1.

\begin{tabular}{|c|c|c|c|c|c|c|c|c|}
\hline Country & $\begin{array}{c}\text { Number of } \\
\text { Observations }\end{array}$ & GDPpc & $\begin{array}{c}\text { Inflation } \\
(\%)\end{array}$ & $\begin{array}{c}\text { Foreign Bank } \\
\text { Assets } \\
(\%)\end{array}$ & $\begin{array}{c}\text { Creditor } \\
\text { Rights } \\
(1-10)\end{array}$ & $\begin{array}{c}\text { Information } \\
\text { Sharing } \\
(1-5)\end{array}$ & $\begin{array}{l}\text { Enforcement } \\
\text { (days) }\end{array}$ & $\begin{array}{c}\text { Bank } \\
\text { Concentration } \\
(\%)\end{array}$ \\
\hline Albania & 145 & 1326 & 3.38 & 44.60 & 9 & 0 & 390 & 0.76 \\
\hline Armenia & 296 & 780 & 3.67 & 54.53 & 4 & 0.67 & 440 & 0.90 \\
\hline Azerbaijan & 154 & 788 & 3.88 & 4.63 & 7 & 0 & 237 & 0.81 \\
\hline Belarus & 257 & 1423 & 51.70 & 12.00 & 4 & 0 & 275 & 0.72 \\
\hline Bosnia & 123 & 1600 & 2.78 & 73.90 & 4 & 4 & 595 & 0.51 \\
\hline Bulgaria & 220 & 1787 & 4.37 & 76.87 & 6 & 2.67 & 564 & 0.59 \\
\hline Croatia & 124 & 5281 & 3.91 & 90.17 & 5 & 0 & 561 & 0.60 \\
\hline Czech Republic & 261 & 5830 & 2.88 & 87.07 & 6 & 2.67 & 611 & 0.63 \\
\hline Estonia & 116 & 4897 & 3.96 & 97.53 & 4 & 4 & 425 & 0.98 \\
\hline Georgia & 89 & 791 & 4.91 & 20.80 & 5 & 0 & 285 & 0.76 \\
\hline Hungary & 436 & 4942 & 8.37 & 78.33 & 6 & 5 & 395 & 0.63 \\
\hline Kazakhstan & 448 & 1534 & 9.23 & 5.50 & 5 & 4 & 390 & 0.66 \\
\hline Kyrgyzstan & 143 & 296 & 4.44 & 48.17 & 4 & 1 & 260 & 0.85 \\
\hline Latvia & 131 & 3867 & 2.96 & 53.67 & 8 & 1 & 369 & 0.55 \\
\hline Lithuania & 107 & 3809 & -0.32 & 89.97 & 4 & 5 & 275 & 0.81 \\
\hline Macedonia & 123 & 1719 & 3.35 & 47.37 & 6 & 4 & 370 & 0.80 \\
\hline Moldova & 235 & 406 & 12.26 & 35.60 & 6 & 0 & 352 & 0.78 \\
\hline Poland & 738 & 4637 & 2.04 & 71.47 & 4 & 3 & 830 & 0.69 \\
\hline Romania & 393 & 1883 & 28.28 & 53.03 & 5 & 3.33 & 512 & 0.66 \\
\hline Russia & 407 & 1986 & 15.25 & 8.10 & 3 & 0 & 281 & 0.29 \\
\hline Slovakia & 133 & 5787 & 4.73 & 86.23 & 9 & 3 & 565 & 0.83 \\
\hline Slovenia & 152 & 10681 & 7.26 & 17.00 & 6 & 4 & 1290 & 0.71 \\
\hline Ukraine & 458 & 756 & 7.76 & 12.17 & 8 & 0 & 343 & 0.54 \\
\hline Total & 5689 & 2835 & 9.68 & 47.52 & 5.36 & 2.15 & 481.89 & 0.66 \\
\hline
\end{tabular}


Table 5: Heterogeneity of firms with and without demand for loans

Notes: Panel A reports differences in means of firm characteristics for the subsample of firms that do not use loans (usage $=0)$, panel B for the whole sample. For continuous variables the results of a two-sample t-test with equal variances and for binary variables the results from a two-sample proportion test are provided in the last column. ${ }^{* * *},{ }^{* *},{ }^{* *}$ denote that the difference in means is statistically significant from zero at a $0.01,0.05$, and 0.10 level.

\begin{tabular}{lccc}
\hline \multicolumn{4}{c}{ Panel A: Subsample of firms that do not use loans } \\
& Demand & No Demand & Difference \\
\hline Age (in years) & 13.607 & 15.125 & $-1.517^{* *}$ \\
Age 0-7 & 0.372 & 0.301 & $0.071^{* * *}$ \\
Age 8-13 & 0.365 & 0.408 & $-0.043^{* *}$ \\
Age 14+ & 0.263 & 0.291 & $-0.028^{*}$ \\
Foreign & 0.051 & 0.114 & $-0.064^{* * *}$ \\
State-owned & 0.076 & 0.107 & $-0.031^{* * *}$ \\
Private & 0.874 & 0.779 & $0.094^{* * *}$ \\
Privatized & 0.874 & 0.779 & $0.095^{* * *}$ \\
Small & 0.850 & 0.731 & $0.119^{* * *}$ \\
Transparancy & 0.420 & 0.599 & $-0.179^{* * *}$ \\
Profitability & 0.790 & 0.859 & $-0.069^{* * *}$ \\
Capacity & 80.454 & 85.308 & $-4.855^{* * *}$ \\
\hline Observations & 1164 & 1830 & \\
& & & \\
Panel B: All firms & \multicolumn{3}{c}{} \\
& Demand & No Demand & Difference \\
\hline Age (in years) & 15.656 & 15.125 & 0.531 \\
Age 0-7 & 0.302 & 0.301 & 0.001 \\
Age 8-13 & 0.390 & 0.408 & -0.018 \\
Age 14+ & 0.308 & 0.291 & 0.017 \\
Foreign & 0.083 & 0.114 & $-0.032^{* * *}$ \\
State-owned & 0.063 & 0.107 & $-0.043^{* * *}$ \\
Private & 0.854 & 0.779 & $0.075^{* * *}$ \\
Privatized & 0.154 & 0.115 & $0.039^{* * *}$ \\
Small & 0.680 & 0.731 & $-0.051^{* * *}$ \\
Transparancy & 0.652 & 0.599 & $0.053^{* * *}$ \\
Profitability & 0.846 & 0.859 & -0.013 \\
Capacity & 81.325 & 85.308 & $-3.983^{* * *}$ \\
\hline Observations & 3859 & 1830 & \\
\hline \hline
\end{tabular}

Table 6: Distribution of perceived access among groups

\begin{tabular}{clc}
\hline Perceived Access & Mean & SD \\
\hline Demand & & \\
0 & 3.135 & 1.021 \\
1 & 2.516 & 1.133 \\
$\Delta$ & $0.619^{* * *}$ & \\
Access & & \\
0 & 2.516 & 1.078 \\
1 & 2.670 & 1.121 \\
$\Delta$ & $-0.510^{* * *}$ & \\
Usage & & \\
0 & 2.756 & 1.147 \\
1 & 2.670 & 1.121 \\
$\Delta$ & $0.086^{* * *}$ & \\
\hline All firms & 2.715 & 1.135 \\
\hline \hline
\end{tabular}


Table 7: Access to loans

Notes: The table presents marginal effects at the mean from the basic regressions for access to loans. In the probit regressions with sample selection (columns 3-4) the dependent variable in the outcome regression is access to loans, while demand for loans is the dependent variable in the selection equation. Standard errors are clustered on country-level and are reported in parentheses. The left out category for age is age 8-13 (firms founded during transition), for nationality privately-owned firms and mining and quarrying for sectors. The correlation between the error terms $\rho$ is indirectly estimated through atanh $\rho .^{* * *},{ }^{* *}{ }^{* *}$ denote that the marginal effect is significantly different from zero at a 0.01 , 0.05 and 0.10 level.

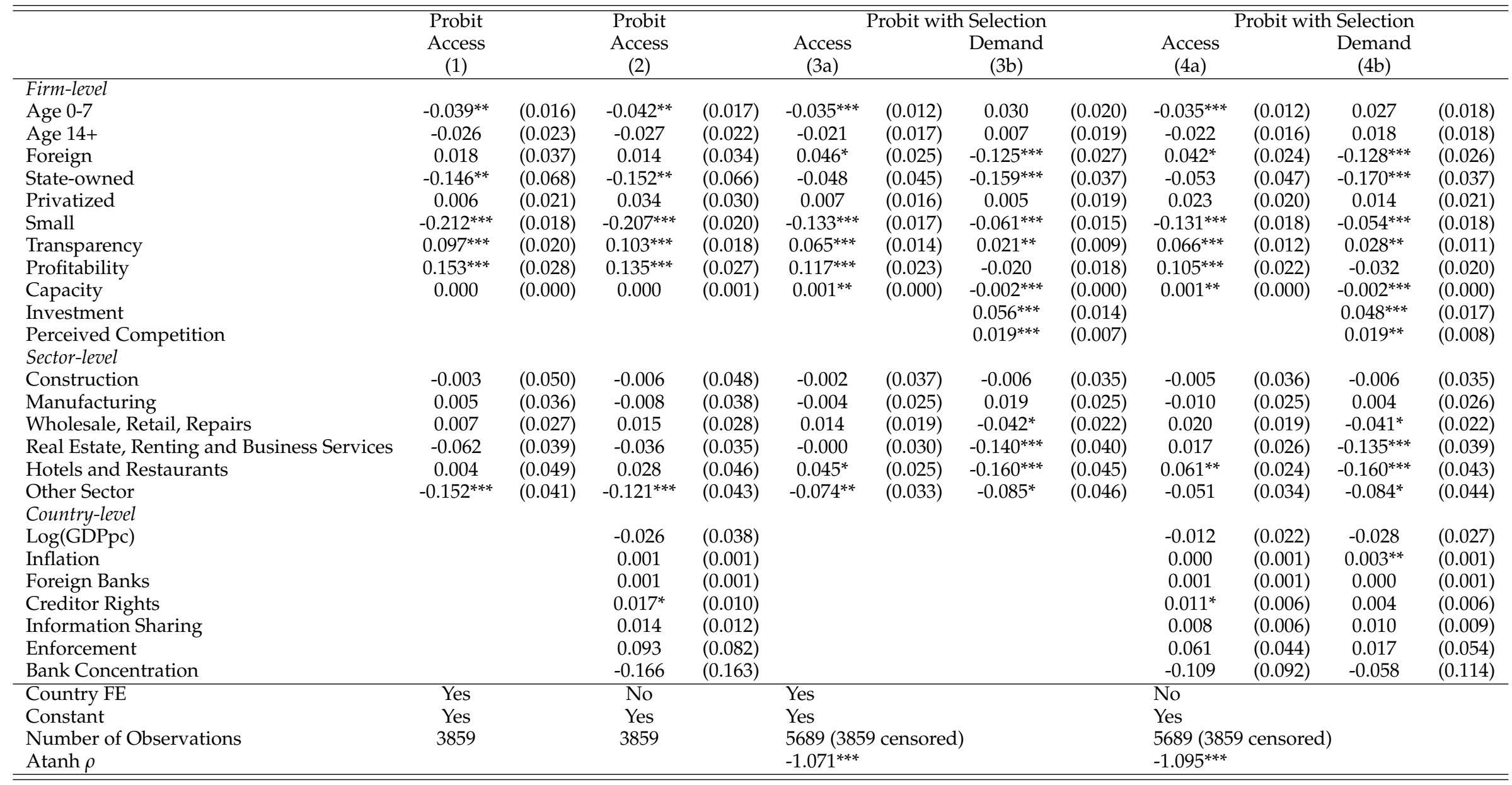


Table 8: Usage of loans

Notes: The table presents the marginal effects at the mean from the probit regressions of usage of loans (column 1-2) and the outcome equation of the probit regressions with sample selection for access to loans (column 3-4, see also Table 7). Standard errors are clustered on country-level and are reported in parentheses. The left out category for age is age 8-13 (firms founded during transition), for nationality privately-owned firms and mining and quarrying for sectors. ${ }^{* * *}, * * * *$ denote that the marginal effect is significantly different from zero at a $0.01,0.05$ and 0.10 level.

\begin{tabular}{|c|c|c|c|c|c|c|c|c|}
\hline \multirow[b]{3}{*}{ Firm-level } & \multicolumn{4}{|c|}{ Usage of Loans } & \multicolumn{4}{|c|}{ Access to Loans } \\
\hline & \multirow[t]{2}{*}{$(1)$} & \multicolumn{2}{|c|}{ (2) } & \multirow[b]{3}{*}{$(0.018)$} & \multirow[t]{2}{*}{ (3) } & \multicolumn{2}{|c|}{ (4) } & \multirow[b]{3}{*}{$(0.012)$} \\
\hline & & & & & & & & \\
\hline Age 0-7 & -0.013 & $(0.018)$ & -0.016 & & $-0.035^{* * *}$ & $(0.012)$ & $-0.035^{* * *}$ & \\
\hline Age 14+ & -0.010 & $(0.021)$ & -0.006 & $(0.020)$ & -0.021 & $(0.017)$ & -0.022 & $(0.016)$ \\
\hline Foreign & $-0.096^{* * *}$ & $(0.027)$ & $-0.098^{* * *}$ & $(0.027)$ & $0.046^{*}$ & $(0.025)$ & $0.042^{*}$ & $(0.024)$ \\
\hline State-owned & $-0.198^{* * *}$ & $(0.045)$ & $-0.201^{* * *}$ & $(0.045)$ & -0.048 & $(0.045)$ & -0.053 & $(0.047)$ \\
\hline Privatized & 0.003 & $(0.022)$ & 0.031 & $(0.029)$ & 0.007 & $(0.016)$ & 0.023 & $(0.020)$ \\
\hline Small & $-0.203^{* * *}$ & $(0.021)$ & $-0.188^{* * *}$ & $(0.025)$ & $-0.133^{* * *}$ & $(0.017)$ & $-0.131^{* * *}$ & $(0.018)$ \\
\hline Transparency & $0.080^{* * *}$ & $(0.014)$ & $0.090^{* * *}$ & $(0.016)$ & $0.065^{* * *}$ & $(0.014)$ & $0.066^{* * *}$ & $(0.012)$ \\
\hline Profitability & $0.095^{* * *}$ & (0.018) & $0.074^{* * *}$ & $(0.020)$ & $0.117^{* * * *}$ & $(0.023)$ & $0.105^{* * *}$ & $(0.022)$ \\
\hline Capacity & $-0.001^{* * *}$ & $(0.000)$ & $-0.001^{* * *}$ & $(0.001)$ & $0.001^{* *}$ & $(0.000)$ & $0.001^{* *}$ & $(0.000)$ \\
\hline Construction & -0.002 & $(0.041)$ & -0.006 & $(0.039)$ & -0.002 & $(0.037)$ & -0.005 & $(0.036)$ \\
\hline \multicolumn{9}{|l|}{ Sector-level } \\
\hline Manufacturing & 0.015 & $(0.034)$ & -0.003 & $(0.036)$ & -0.004 & $(0.025)$ & -0.010 & $(0.025)$ \\
\hline Wholesale, Retail, Repairs & -0.027 & $(0.025)$ & -0.023 & $(0.026)$ & 0.014 & $(0.019)$ & 0.020 & $(0.019)$ \\
\hline Real Estate, Renting and Business Services & $-0.142^{* * *}$ & $(0.028)$ & $-0.130^{* * *}$ & $(0.028)$ & -0.000 & $(0.030)$ & 0.017 & $(0.026)$ \\
\hline Hotels and Restaurants & $-0.121^{* *}$ & $(0.051)$ & $-0.112^{* *}$ & $(0.048)$ & $0.045^{*}$ & $(0.025)$ & $0.061^{* *}$ & $(0.024)$ \\
\hline Other Sector & $-0.159^{* * *}$ & $(0.038)$ & $-0.148^{* * *}$ & $(0.037)$ & $-0.074^{* *}$ & $(0.033)$ & -0.051 & $(0.034)$ \\
\hline \multicolumn{9}{|l|}{ Country-level } \\
\hline $\log (\mathrm{GDPpc})$ & & & -0.037 & $(0.041)$ & & & -0.012 & $(0.022)$ \\
\hline Inflation & & & 0.003 & $(0.002)$ & & & 0.000 & $(0.001)$ \\
\hline Foreign Banks & & & 0.001 & $(0.001)$ & & & 0.001 & $(0.001)$ \\
\hline Creditor Rights & & & $0.015^{*}$ & $(0.009)$ & & & $0.011^{*}$ & $(0.006)$ \\
\hline Information Sharing & & & 0.017 & $(0.014)$ & & & 0.008 & $(0.006)$ \\
\hline Enforcement & & & 0.074 & $(0.090)$ & & & 0.061 & $(0.044)$ \\
\hline Bank Concentration & & & -0.156 & $(0.172)$ & & & -0.109 & $(0.092)$ \\
\hline Country FE & Yes & & No & & Yes & & No & \\
\hline Constant & Yes & & Yes & & Yes & & Yes & \\
\hline Number of Observations & 5689 & & 5689 & & $5689(3859$ & censored) & $5689(385$ & censored) \\
\hline
\end{tabular}




\section{Table 9: Bootstrap Hausman test}

Note: The table presents the results of a Bootstrap Hausman test of equal estimators. The difference in coefficients was bootstrapped with 400 replications. Column one and two present the difference between the coefficients in the use and the access specification, bootstrapped standard errors of the differences are in parentheses. The left out category for age is age 8-13 (firms founded during transition), for nationality privately-owned firms and mining and quarrying for sectors. $* * *, * * * *$ denote that the difference in coefficients is statistically significant from zero at a $0.01,0.05$, and 0.10 level.

\begin{tabular}{|c|c|c|c|c|}
\hline \multirow[b]{2}{*}{ Firm-level } & \multicolumn{2}{|c|}{$\begin{array}{l}\text { Difference in } \\
\text { Coefficients } \\
\text { (Usage-Access) } \\
\text { (1) }\end{array}$} & \multicolumn{2}{|c|}{$\begin{array}{l}\text { Difference in } \\
\text { Coefficients } \\
\text { (Usage-Access) } \\
\text { (2) }\end{array}$} \\
\hline & & & & \\
\hline Age 0-7 & $0.085^{* *}$ & $(0.037)$ & $0.083^{* *}$ & $(0.037)$ \\
\hline Age 14+ & 0.058 & $(0.044)$ & 0.068 & $(0.043)$ \\
\hline Foreign & $-0.303^{* * *}$ & $(0.079)$ & $-0.294^{* * *}$ & $(0.073)$ \\
\hline State-owned & -0.119 & $(0.075)$ & $-0.117^{*}$ & $(0.071)$ \\
\hline Privatized & -0.020 & $(0.055)$ & -0.036 & $(0.054)$ \\
\hline Small & $0.200^{* * *}$ & $(0.046)$ & $0.204^{* * *}$ & $(0.045)$ \\
\hline Transparency & $-0.093^{* * *}$ & $(0.031)$ & $-0.083^{* * *}$ & $(0.028)$ \\
\hline Profitability & $-0.190^{* * *}$ & $(0.039)$ & $-0.191^{* * *}$ & $(0.038)$ \\
\hline Capacity & $-0.004^{* * *}$ & $(0.001)$ & $-0.004^{* * *}$ & $(0.001)$ \\
\hline \multicolumn{5}{|l|}{ Sector-level } \\
\hline Construction & $-0.264^{*}$ & $(0.152)$ & -0.219 & $(0.154)$ \\
\hline Manufacturing & $-0.241^{*}$ & $(0.146)$ & -0.206 & $(0.147)$ \\
\hline Wholesale, Retail, Repairs & $-0.358^{* *}$ & $(0.148)$ & $-0.329^{* *}$ & $(0.151)$ \\
\hline Real Estate, Renting and Business Services & $-0.454^{* * *}$ & $(0.160)$ & $-0.455^{* * *}$ & $(0.161)$ \\
\hline Hotels and Restaurants & $-0.589^{* * *}$ & $(0.176)$ & $-0.598^{* * *}$ & $(0.177)$ \\
\hline Other Sector & $-0.284^{*}$ & $(0.152)$ & $-0.257^{*}$ & $(0.154)$ \\
\hline \multicolumn{5}{|l|}{ Country-level } \\
\hline Log(GDPpc) & & & -0.016 & $(0.032)$ \\
\hline Inflation & & & 0.002 & $(0.001)$ \\
\hline Foreign Banks & & & $-0.001^{*}$ & $(0.001)$ \\
\hline Creditor Rights & & & -0.012 & $(0.010)$ \\
\hline Information Sharing & & & 0.001 & $(0.011)$ \\
\hline Enforcement & & & $-0.093^{*}$ & $(0.055)$ \\
\hline Bank Concentration & & & 0.097 & $(0.130)$ \\
\hline Country FE & Yes & & No & \\
\hline Constant & Yes & & Yes & \\
\hline Number of Observations & 5689 & & 5689 & \\
\hline
\end{tabular}


Table 10: Perceived access to finance

Notes: The table presents coefficient estimates from the OLS regressions for the perception-based indicator access to finance. The dependent variable measures how problematic access to finance is for the operation and growth of a company and varies from 1 major obstacle to 4 no obstacle. Standard errors are clustered on country-level and are reported in parentheses. The left out category for age is age 8-13 (firms founded during transition), for nationality privately-owned firms and mining and quarrying for sectors. ${ }^{* * *}, * * * *$ denote that the coefficient is significantly different from zero at a $0.01,0.05$ and 0.10 level.

\begin{tabular}{|c|c|c|c|c|c|c|c|c|c|c|c|c|}
\hline \multirow[b]{3}{*}{ Firm-level } & \multicolumn{4}{|c|}{ All Firms } & \multicolumn{4}{|c|}{ Firms with Demand } & \multicolumn{4}{|c|}{ Firms without Demand } \\
\hline & \multirow[t]{2}{*}{$(1)$} & \multicolumn{2}{|c|}{ (2) } & \multirow[b]{3}{*}{$(0.040)$} & \multirow[t]{2}{*}{ (3) } & \multicolumn{2}{|c|}{$(4)$} & \multirow[b]{3}{*}{$(0.044)$} & \multirow[t]{2}{*}{ (5) } & \multicolumn{3}{|c|}{ (6) } \\
\hline & & & & & & & & & & & & \\
\hline Age $0-7$ & -0.056 & $(0.040)$ & $-0.108^{* *}$ & & -0.053 & $(0.046)$ & $-0.111^{* *}$ & & -0.043 & $(0.046)$ & -0.062 & $(0.047)$ \\
\hline Age 14+ & -0.062 & $(0.058)$ & -0.043 & $(0.037)$ & -0.124 & $(0.076)$ & $-0.097^{*}$ & $(0.054)$ & 0.051 & $(0.056)$ & $0.097^{*}$ & $(0.052)$ \\
\hline Foreign & $0.280^{* * *}$ & $(0.060)$ & $0.276^{* * *}$ & $(0.062)$ & $0.252^{* * *}$ & $(0.079)$ & $0.260^{* * *}$ & $(0.078)$ & 0.148 & $(0.093)$ & 0.157 & $(0.098)$ \\
\hline State-owned & 0.082 & $(0.077)$ & 0.056 & $(0.070)$ & -0.056 & $(0.072)$ & -0.070 & $(0.076)$ & 0.024 & $(0.123)$ & 0.003 & $(0.114)$ \\
\hline Privatized & $0.119^{*}$ & $(0.067)$ & 0.098 & $(0.065)$ & $0.142^{*}$ & $(0.081)$ & 0.119 & $(0.085)$ & 0.058 & $(0.075)$ & 0.058 & $(0.068)$ \\
\hline Small & $-0.181^{* * *}$ & $(0.040)$ & $-0.177^{* * *}$ & $(0.046)$ & $-0.227^{* * *}$ & $(0.055)$ & $-0.242^{* * *}$ & $(0.061)$ & $-0.196^{* * *}$ & $(0.068)$ & $-0.155^{* *}$ & $(0.070)$ \\
\hline Transparency & $0.067^{* *}$ & $(0.026)$ & $0.093^{* * *}$ & $(0.030)$ & $0.095^{* * *}$ & $(0.028)$ & $0.114^{* * *}$ & $(0.036)$ & 0.050 & $(0.042)$ & $0.092^{* *}$ & $(0.040)$ \\
\hline Profitability & $0.166^{* *}$ & $(0.067)$ & $0.136^{*}$ & $(0.068)$ & $0.197^{* *}$ & $(0.073)$ & $0.154^{*}$ & $(0.079)$ & 0.081 & $(0.089)$ & 0.051 & $(0.091)$ \\
\hline Capacity & $0.005^{* * *}$ & $(0.001)$ & $0.005^{* * *}$ & $(0.001)$ & $0.005^{* * *}$ & $(0.001)$ & $0.006^{* * *}$ & $(0.001)$ & -0.000 & $(0.002)$ & -0.001 & $(0.002)$ \\
\hline \multicolumn{13}{|l|}{ Sector-level } \\
\hline Construction & -0.016 & $(0.108)$ & -0.058 & $(0.107)$ & -0.058 & $(0.134)$ & -0.100 & $(0.132)$ & 0.108 & $(0.107)$ & 0.060 & $(0.109)$ \\
\hline Manufacturing & -0.011 & $(0.087)$ & -0.094 & $(0.094)$ & 0.027 & $(0.112)$ & -0.060 & $(0.119)$ & -0.033 & $(0.091)$ & -0.145 & $(0.095)$ \\
\hline Wholesale, Retail, Repairs & 0.108 & $(0.084)$ & 0.094 & $(0.086)$ & 0.106 & $(0.087)$ & 0.098 & $(0.088)$ & 0.043 & $(0.113)$ & 0.019 & $(0.115)$ \\
\hline Real Estate, Renting and Business Services & $0.240^{* * *}$ & $(0.082)$ & $0.243^{* * *}$ & $(0.080)$ & $0.173^{*}$ & $(0.086)$ & $0.215^{* *}$ & $(0.081)$ & 0.135 & $(0.100)$ & 0.088 & $(0.104)$ \\
\hline Hotels and Restaurants & $0.241^{* *}$ & $(0.116)$ & $0.239 *$ & $(0.122)$ & 0.180 & $(0.127)$ & 0.214 & $(0.136)$ & 0.072 & $(0.127)$ & 0.036 & $(0.140)$ \\
\hline Other Sector & 0.067 & $(0.121)$ & 0.061 & $(0.131)$ & -0.009 & $(0.126)$ & 0.000 & $(0.140)$ & 0.030 & $(0.136)$ & -0.006 & $(0.138)$ \\
\hline \multicolumn{13}{|l|}{ Country-level } \\
\hline $\log (\mathrm{GDPpc})$ & & & $0.158^{*}$ & $(0.080)$ & & & 0.152 & $(0.091)$ & & & 0.129 & $(0.091)$ \\
\hline Inflation & & & $-0.007^{* *}$ & $(0.003)$ & & & $-0.007^{*}$ & $(0.004)$ & & & -0.004 & $(0.003)$ \\
\hline Foreign Banks & & & -0.003 & $(0.002)$ & & & -0.003 & $(0.003)$ & & & -0.003 & $(0.002)$ \\
\hline Creditor Rights & & & 0.023 & $(0.030)$ & & & 0.026 & $(0.036)$ & & & 0.022 & $(0.026)$ \\
\hline Information Sharing & & & 0.012 & $(0.034)$ & & & 0.009 & $(0.040)$ & & & 0.036 & $(0.028)$ \\
\hline Enforcement & & & $-0.432 * *$ & (0.189) & & & $-0.427^{*}$ & $(0.230)$ & & & $-0.422 * *$ & $(0.151)$ \\
\hline Bank Concentration & & & 0.136 & $(0.323)$ & & & 0.380 & $(0.341)$ & & & -0.420 & $(0.365)$ \\
\hline Country FE & Yes & & No & & Yes & & No & & Yes & & No & \\
\hline Constant & Yes & & Yes & & Yes & & Yes & & Yes & & Yes & \\
\hline R-squared & 0.081 & & 0.065 & & 0.099 & & 0.073 & & 0.081 & & 0.059 & \\
\hline Number of Observations & 5689 & & 5689 & & 3859 & & 3859 & & 1830 & & 1830 & \\
\hline
\end{tabular}


Appendix A. Appendix

Table A.1: Definition of variables

\begin{tabular}{|c|c|}
\hline Firm-level & Definition and source \\
\hline Age 0-7 & Firm has been established after transition (after 1998). BEEPS 2005 (s1a) \\
\hline Age 14+ & Firm has been established during transition (1991-1997). BEEPS 2005 (s1a) \\
\hline Foreign & Largest shareholder is a foreign company. BEEPS 2005 (q4aa) \\
\hline Privatized & $\begin{array}{l}\text { Firm has been established through privatization of a state-owned firm. BEEPS } \\
2005 \text { (q5a) }\end{array}$ \\
\hline State-owned & $\begin{array}{l}\text { Legal status of company is either state/ municipal/ district-owned, } \\
\text { corporatised state-owned or other state-owned enterprise. BEEPS } 2005 \text { (s2a) }\end{array}$ \\
\hline Small & Firm has less than 50 employees. BEEPS $2005(\mathrm{~s} 4 \mathrm{~b})$ \\
\hline Transparency & $\begin{array}{l}\text { Following Brown et al. (2009) this variable is based one the usage of } \\
\text { international accounting standards (q48) and external auditors. It equals } 0 \text { if } \\
\text { the firm does not use international accounting standards or external auditors, } \\
1 \text { if the firms uses one of the two and } 2 \text { if both are used. BEEPS } 2005 \text { (q48, q49) }\end{array}$ \\
\hline Profitability & Firm has realized positive profits in 2003. BEEPS 2005 (q59b) \\
\hline Capacity & Output in comparison with the maximum output possible. BEEPS (q65a1) \\
\hline Perceived Competition & $\begin{array}{l}\text { Firms are asked to answer the hypothetical question, how customers would } \\
\text { react if the firm rise the price of the main product or service by ten percent. It } \\
\text { varies from } 1 \text { (customer would continue to buy) to } 4 \text { (many of the costumers } \\
\text { would buy from competitors instead). BEEPS } 2005 \text { (q11) }\end{array}$ \\
\hline Investment & $\begin{array}{l}\text { Firm has acquired new production technology over the last } 36 \text { months. BEEPS } \\
2005 \text { (q61a) }\end{array}$ \\
\hline Sector dummies & $\begin{array}{l}\text { More than } 50 \text { percent of the sales of a company comes from this sector. The } \\
\text { majority of the firms operates in a single sector. The sectors are mining } \\
\text { and quarrying (sector 1), construction (Sector Construction), manufacturing } \\
\text { (Sector Manufacturing), wholesale, retail and repairs (Sector Wholesale, retail, } \\
\text { repairs), real estate, renting and business services (Sector Real Estate), hotels } \\
\text { and restaurants (Sector Hotels and restaurants) and others (Sector Others). }\end{array}$ \\
\hline Country & Definition and source \\
\hline $\log (\mathrm{GDPpc})$ & $\begin{array}{l}\text { Logarithm of GDP per capita (current US\$). Average values for the years } \\
\text { 2001-2003. Source: World Bank }\end{array}$ \\
\hline Inflation & $\begin{array}{l}\text { Inflation, consumer prices (annual percentage). Average values for the years } \\
\text { 2001-2003. Source: World Bank }\end{array}$ \\
\hline Foreign Bank Assets & $\begin{array}{l}\text { Asset share of foreign-owned banks (in percentage). Average values for the } \\
\text { years 2001-2003. Source: EBRD (2005) }\end{array}$ \\
\hline Creditor Rights & $\begin{array}{l}\text { The index measures the degree to which collateral and bankruptcy laws } \\
\text { protect the rights of borrowers and lenders and thus facilitate lending. } 2005 \\
\text { value (earlier values not available). Source: World Bank: Doing Business, } \\
\text { Getting Credit }\end{array}$ \\
\hline Enforcement & $\begin{array}{l}\text { Logarithm of time (in days) to resolve a dispute, counted from the moment } \\
\text { the plaintiff files the lawsuit in court until payment. This includes both the } \\
\text { days when actions take place and the waiting periods between. } 2005 \text { values } \\
\text { (earlier values not available). Source: World Bank, Doing Business, Enforcing } \\
\text { Contracts }\end{array}$ \\
\hline Information Sharing & $\begin{array}{l}\text { Based on information from the Doing Business in } 2006 \text { report (World Bank, } \\
\text { 2006), Brown et al. (2009) compute for each country and year one index for } \\
\text { private credit bureaus and one for public credit registries that account for the } \\
\text { existence and coverage of these institutions. The maximum value of both } \\
\text { indixes is taken to approximate the level of information sharing. Average } \\
\text { values for the years 2001-2003. Source: Brown et al. (2009) }\end{array}$ \\
\hline Bank Concentration & $\begin{array}{l}\text { Assets of the three largest banks as a share of assets of all commercial banks. } \\
\text { Average values for the years 2001-2003. Source: Beck and Demirgüç-Kunt } \\
\text { (2009) }\end{array}$ \\
\hline
\end{tabular}


Table A.2: Heckman two-step estimator

Notes: The table presents marginal effects at the mean from the Heckman two-step estimation for access to loans. The dependent variable in the outcome regression is access to loans, while demand for loans is the dependent variable in the selection equation. Standard errors are clustered on country-level and are reported in parentheses. The left out category for age is age 8-13 (firms founded during transition), for nationality privately-owned firms and mining and quarrying for sectors. ${ }^{* * *}$, ${ }^{* * *}$ denote that the marginal effect is significantly different from zero at a $0.01,0.05$ and 0.10 level.

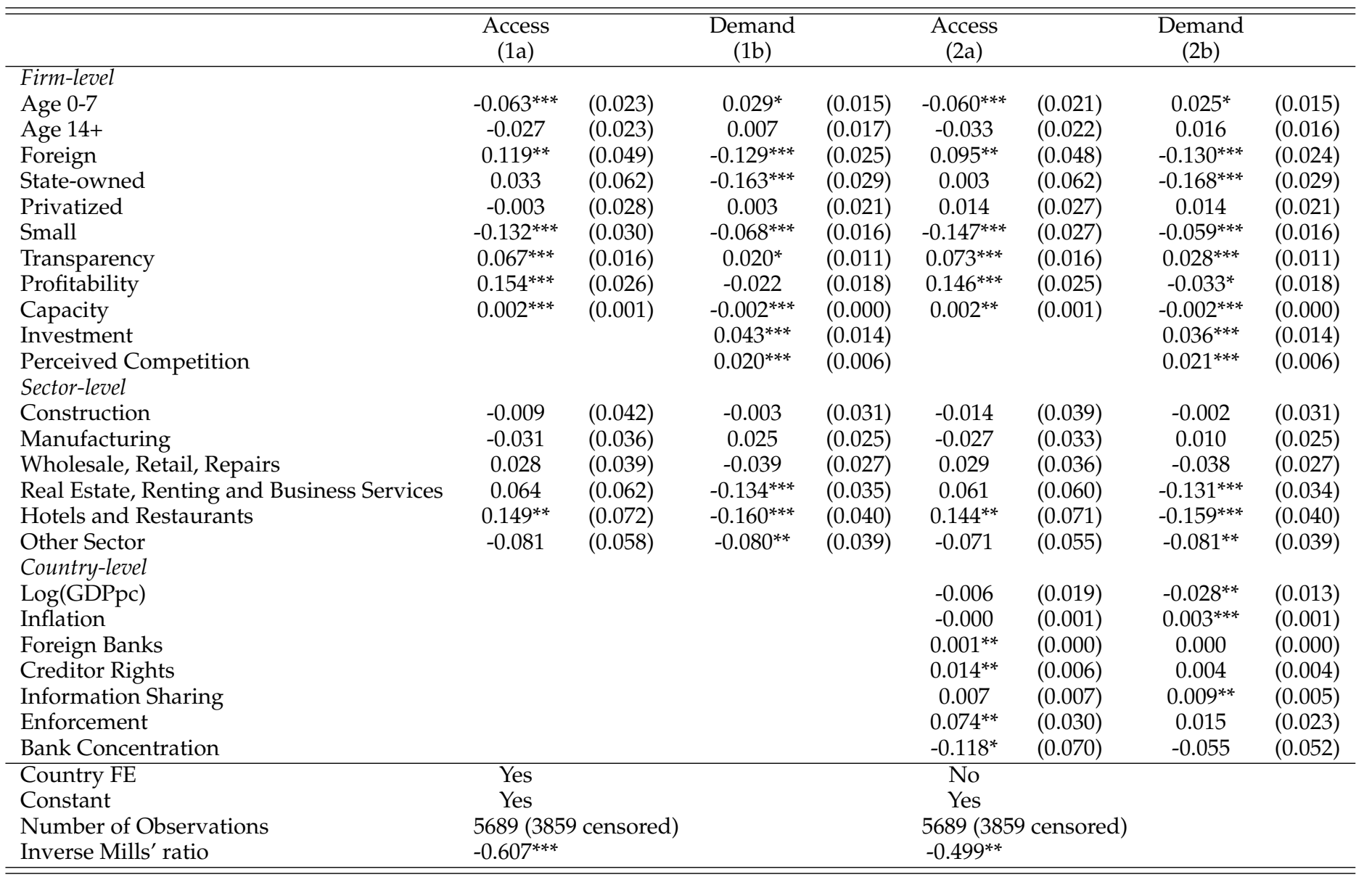


Table A.3: IV regressions

Notes: The table presents the coefficient estimates from the linear IV regressions of usage of loans (column 1-2) and access to loans (column 3-4). Profitability is instrumented by the industry-country averages of profitability. Standard errors are clustered on country-level and are reported in parentheses. The left out category for age is age 8-13 (firms founded during transition), for nationality privately-owned firms and mining and quarrying for sectors. ${ }^{* * *},{ }^{* *},{ }^{* *}$ denote that the marginal effect is significantly different from zero at a $0.01,0.05$ and 0.10 level.

\begin{tabular}{|c|c|c|c|c|c|c|c|c|}
\hline & $\begin{array}{c}\text { Usage-IV } \\
\text { (1) }\end{array}$ & & $\begin{array}{c}\text { Usage-IV } \\
\text { (2) }\end{array}$ & & $\begin{array}{c}\text { Access-IV } \\
\text { (3) }\end{array}$ & & $\begin{array}{c}\text { Access-IV } \\
(4)\end{array}$ & \\
\hline \multicolumn{9}{|l|}{ Firm-level } \\
\hline Age $0-7$ & -0.006 & $(0.032)$ & -0.011 & $(0.021)$ & -0.083 & $(0.417)$ & $-0.041^{* *}$ & $(0.021)$ \\
\hline Age 14+ & 0.045 & $(0.078)$ & -0.026 & $(0.022)$ & -0.211 & (1.728) & -0.030 & $(0.023)$ \\
\hline Foreign & -0.022 & $(0.080)$ & $-0.121^{* * *}$ & $(0.033)$ & -0.338 & (3.220) & -0.010 & $(0.044)$ \\
\hline State-owned & 0.286 & $(0.507)$ & $-0.399 * * *$ & $(0.151)$ & -3.882 & $(35.081)$ & -0.244 & $(0.249)$ \\
\hline Privatized & 0.236 & $(0.244)$ & -0.074 & $(0.072)$ & -2.009 & (18.729) & -0.042 & $(0.128)$ \\
\hline Small & $-0.144^{* *}$ & $(0.060)$ & $-0.196^{* * *}$ & $(0.026)$ & -0.670 & $(4.467)$ & $-0.204^{* * *}$ & $(0.022)$ \\
\hline Transparency & 0.039 & $(0.039)$ & $0.109^{* * *}$ & $(0.023)$ & 0.226 & (1.311) & $0.104^{* * *}$ & $(0.031)$ \\
\hline Profitability & 2.362 & $(2.323)$ & -0.880 & $(0.747)$ & -15.845 & $(148.694)$ & -0.375 & $(1.062)$ \\
\hline \multirow{2}{*}{\multicolumn{9}{|c|}{ Sector-level }} \\
\hline & & & & & & & & \\
\hline Construction & 0.109 & $(0.207)$ & -0.108 & $(0.092)$ & -0.835 & (8.199) & -0.000 & $(0.105)$ \\
\hline Manufacturing & 0.179 & $(0.243)$ & -0.122 & (0.101) & -1.127 & $(10.970)$ & -0.010 & (0.118) \\
\hline Wholesale, Retail, Repairs & 0.151 & $(0.257)$ & -0.164 & $(0.102)$ & -1.160 & (11.172) & 0.002 & $(0.122)$ \\
\hline Real Estate, Renting and Business Services & 0.055 & $(0.263)$ & $-0.265^{* *}$ & $(0.103)$ & -1.672 & (15.508) & -0.057 & $(0.147)$ \\
\hline Hotels and Restaurants & 0.018 & $(0.224)$ & $-0.220^{* *}$ & $(0.094)$ & -1.522 & $(14.691)$ & 0.010 & $(0.140)$ \\
\hline Other Sector & 0.226 & $(0.351)$ & $-0.246^{*}$ & $(0.136)$ & -1.832 & $(16.984)$ & -0.065 & $(0.157)$ \\
\hline \multicolumn{9}{|l|}{ Country-level } \\
\hline $\log (\mathrm{GDPpc})$ & & & 0.006 & $(0.034)$ & & & -0.001 & $(0.043)$ \\
\hline Inflation & & & 0.001 & $(0.001)$ & & & 0.000 & $(0.002)$ \\
\hline Foreign Banks & & & 0.000 & $(0.001)$ & & & 0.001 & $(0.001)$ \\
\hline Creditor Rights & & & 0.002 & $(0.016)$ & & & 0.010 & $(0.017)$ \\
\hline Information Sharing & & & 0.001 & $(0.017)$ & & & 0.005 & $(0.018)$ \\
\hline Enforcement & & & 0.041 & $(0.063)$ & & & 0.072 & $(0.053)$ \\
\hline Bank Concentration & & & -0.011 & $(0.132)$ & & & -0.086 & $(0.121)$ \\
\hline Country FE & Yes & & No & & Yes & & No & \\
\hline Constant & Yes & & Yes & & Yes & & Yes & \\
\hline Number of Observations & 5689 & & 5689 & & 3859 & & 3859 & \\
\hline F-Statistics & $2444.1^{* * *}$ & & $2417.4^{* * *}$ & & $328.2^{* * *}$ & & $342.7^{* * *}$ & \\
\hline
\end{tabular}


Table A.4: Standard errors clustered on industry-country-level

Notes: The table presents the marginal effects at the mean from the regressions of usage of loans (column 1-2) and access to loans (column 3-6). Standard errors are clustered on industry-country-level and are reported in parentheses. The left out category for age is age 8-13 (firms founded during transition), for nationality privately-owned firms and mining and quarrying for sectors. The correlation between the error terms $\rho$ is indirectly estimated through atanh $\rho .{ }^{* * *}, * * * *$ denote that the marginal effect is significantly different from zero at a $0.01,0.05$ and 0.10 level.

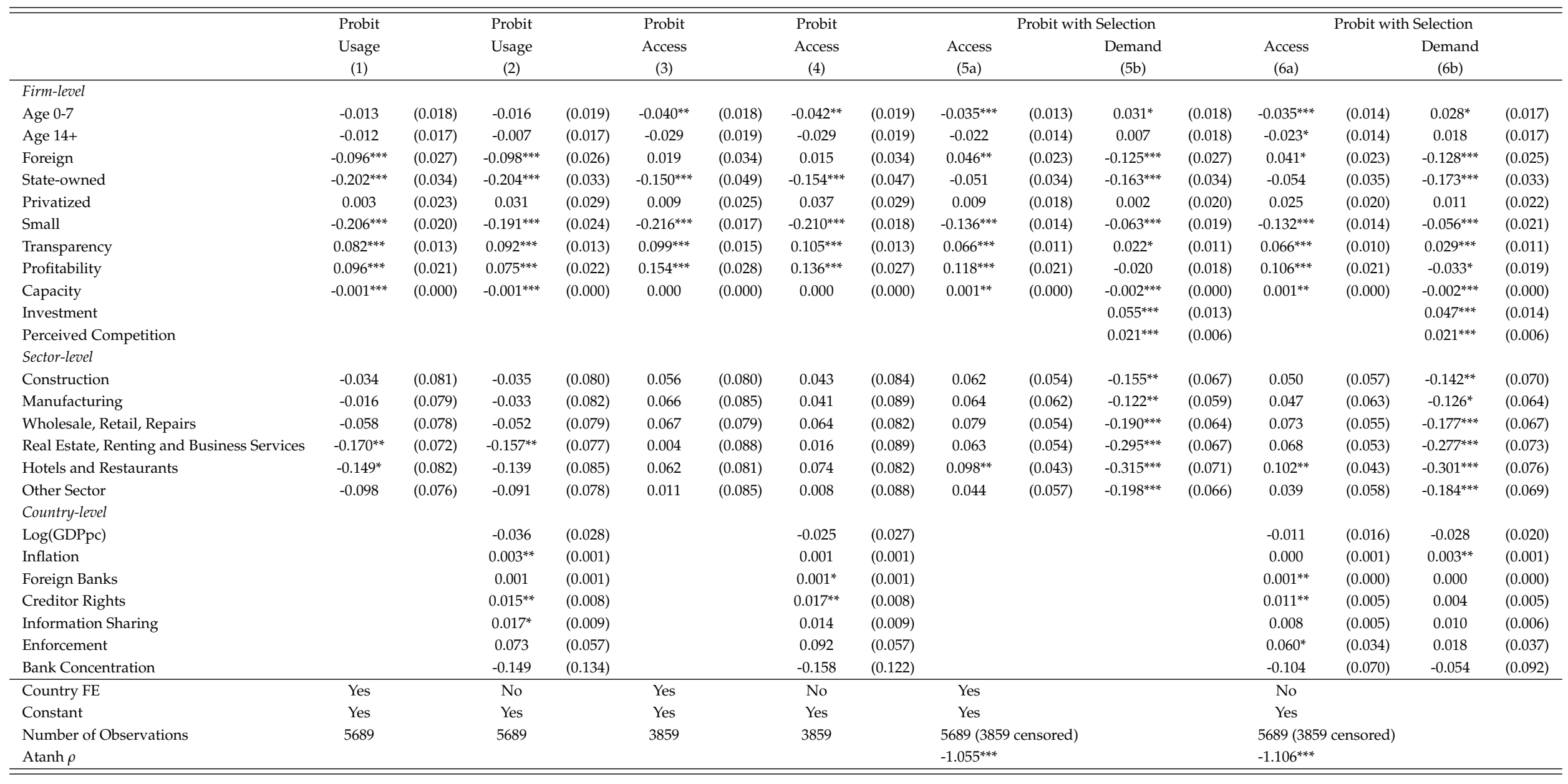

